\title{
Surface formation, preservation, and history of low-porosity crusts at the WAIS Divide site, West Antarctica
}

\author{
John M. Fegyveresi ${ }^{1,2}$, Richard B. Alley ${ }^{2}$, Atsuhiro Muto ${ }^{3}$, Anaïs J. Orsi ${ }^{4}$, and Matthew K. Spencer ${ }^{5}$ \\ ${ }^{1}$ Terrestrial and Cryospheric Sciences Branch, US Cold Regions Research and Engineering \\ Laboratory (CRREL), Hanover, NH 03755, USA \\ ${ }^{2}$ Dept. of Geosciences, and Earth and Environmental Systems Institute, Pennsylvania State \\ University, University Park, PA 16802, USA \\ ${ }^{3}$ Dept. of Earth and Environmental Science, College of Science and Technology, Temple \\ University, Philadelphia, PA 19122, USA \\ ${ }^{4}$ Laboratoire des Sciences du Climat et de l'Environnement, LSCE/IPSL, CEA-CNRS-UVSQ, \\ Université Paris-Saclay, 91191, Gif-sur-Yvette, France \\ ${ }^{5}$ School of Physical Sciences, Lake Superior State University, Sault Sainte Marie, \\ MI 49783, USA
}

Correspondence: John M. Fegyveresi (fegy.john@gmail.com)

Received: 21 June 2016 - Discussion started: 29 June 2016

Revised: 11 November 2017 - Accepted: 28 November 2017 - Published: 26 January 2018

\begin{abstract}
Observations at the West Antarctic Ice Sheet (WAIS) Divide site show that near-surface snow is strongly altered by weather-related processes such as strong winds and temperature fluctuations, producing features that are recognizable in the deep ice core. Prominent "glazed" surface crusts develop frequently at the site during summer seasons. Surface, snow pit, and ice core observations made in this study during summer field seasons from 2008-2009 to 20122013, supplemented by automated weather station (AWS) data with short- and longwave radiation sensors, revealed that such crusts formed during relatively low-wind, lowhumidity, clear-sky periods with intense daytime sunshine. After formation, such glazed surfaces typically developed cracks in a polygonal pattern likely from thermal contraction at night. Cracking was commonest when several clear days occurred in succession and was generally followed by surface hoar growth; vapor escaping through the cracks during sunny days may have contributed to the high humidity that favored nighttime formation of surface hoar. Temperature and radiation observations show that daytime solar heating often warmed the near-surface snow above the air temperature, contributing to upward mass transfer, favoring crust formation from below, and then surface hoar formation. A simple surface energy calculation supports this observa-
\end{abstract}

tion. Subsequent examination of the WDC06A deep ice core revealed that crusts are preserved through the bubbly ice, and some occur in snow accumulated during winters, although not as commonly as in summertime deposits. Although no one has been on site to observe crust formation during winter, it may be favored by greater wintertime wind packing from stronger peak winds, high temperatures and steep temperature gradients from rapid midwinter warmings reaching as high as $-15^{\circ} \mathrm{C}$, and perhaps longer intervals of surface stability. Time variations in crust occurrence in the core may provide paleoclimatic information, although additional studies are required. Discontinuity and cracking of crusts likely explain why crusts do not produce significant anomalies in other paleoclimatic records.

\section{Introduction}

Visual and thin-section examination of the West Antarctic Ice Sheet (WAIS) Divide deep ice core revealed not only an annual signal linked to bubble and grain characteristics (Fitzpatrick et al., 2014) but also numerous crusts. These crusts are bubble-free or nearly so, typically $1 \mathrm{~mm}$ or less and one grain in thickness, and are readily identified visually in bub- 
bly ice (Fig. 1). Their presence in greater abundance than seen in most cores (e.g., Alley, 1988) motivated studies to understand their formation, possible influence on other paleoclimatic data, and potential for recording paleoclimatic conditions themselves.

Work by Orsi et al. (2015) and Mitchell et al. (2015) showed that no significant artifacts are introduced to paleoclimatic records by the WAIS Divide crusts. Here, we report additional studies showing that summertime crusts form under specific conditions linked to persistent high-pressure systems, so the time series of crusts likely contains paleoclimatic information; however, many additional issues must be addressed before useful climate histories can be constructed confidently.

Bubble-free layers much thicker than the bubble-free crusts discussed here are sometimes observed in ice cores from warm sites and provide evidence of refrozen meltwater (e.g., Das and Alley, 2005). These are of interest as paleoclimatic records but have the potential to anomalously distort records of trapped gases or other components of ice cores. Refrozen meltwater can be identified by an excess of trapped heavy noble gases, so Orsi et al. (2015) analyzed WAIS Divide samples containing bubble-free crusts, finding that not enough meltwater was involved to significantly perturb records of other trace gases. Additionally, crusts might greatly modify gas trapping in the firn, but measured nitrogen-isotopic ratios at WAIS Divide show that gravitational fractionation occurs down to the normal trapping depth where normal amounts of air are trapped, demonstrating that the crusts are not both impermeable and laterally extensive at shallow depth (Mitchell et al., 2015; Battle et al., 2011).

Here, we report coordinated observations of crust formation over five summers (2008-2009 to 2012-2013) at the WAIS Divide site, involving daily observations of surface evolution, shallow-snow-pit studies with a $2 \mathrm{~m}$ pit at least once per year, insolation measurements, and near-surface temperature profiling, supplemented with data from an onsite automated weather station (AWS). We find that crusts form most commonly in the summer $(45 \%$ greater occurrence) but do also form in winter. In summer, crust formation primarily results from the effects of strong diurnal temperature cycling under clear-sky, low-wind, relatively warm conditions. Wintertime observations are not available, but the physical understanding gained from our summertime data suggests hypotheses for formation. Time trends in the occurrence of summertime crusts in the core may reveal changes in the frequency of the persistent high-pressure conditions that generate crusts, although additional work will be required to quantify this.

\section{Methods}

The main methods used are described here. Additional details are provided in Fegyveresi (2015). The surface was ob-

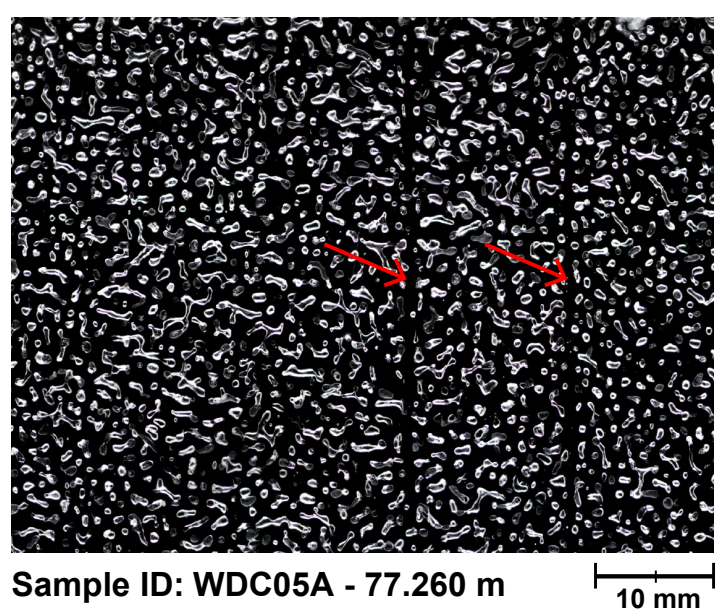

Figure 1. A thick-section image of a sample prepared from a depth of $\sim 77.260 \mathrm{~m}$ showing two preserved crusts. Both layers are $\sim 1 \mathrm{~mm}$ thick and appear mostly bubble-free. All bubbles here appear white, with the surrounding ice black. The general elongated shape of the bubbles is due the proximity of this sample to the bubble close-off depth at WAIS Divide of $\sim 75 \mathrm{~m}$. This sample is from the secondary WDC05A core at the WAIS Divide site. Image modified from Orsi et al. (2015).
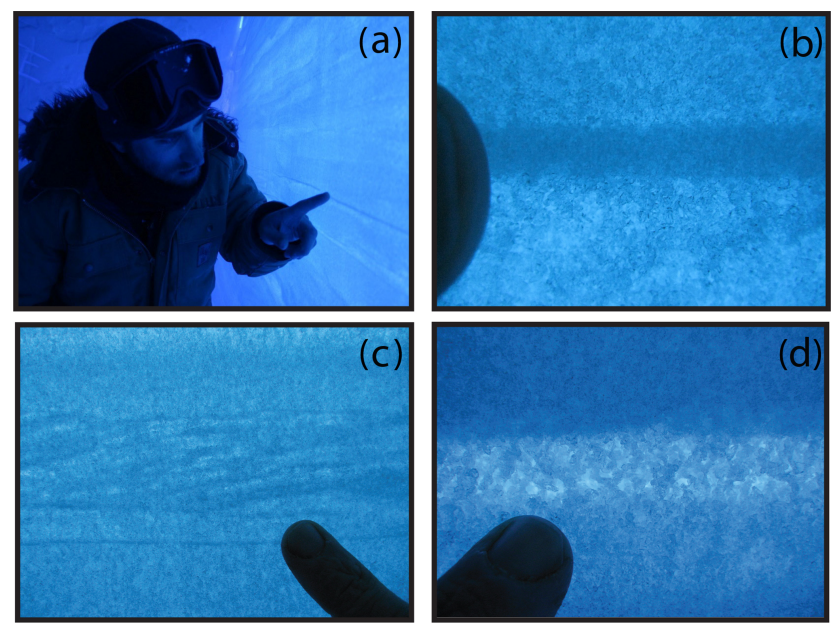

Figure 2. The lead author in a $2 \mathrm{~m}$ snow pit prepared at WAIS Divide (pit 2009-10-A). Multi-grain crusts (a, b), preserved sastrugi with cross-bedding (c), and hoar layers (d) are all easily identifiable.

served continually by one of us (John M. Fegyveresi) during the five field seasons extending from 2008-2009 to 20122013 (Table 1). During each austral summer, a backlit snow pit was also prepared and studied (five total pits). All pits were sited within $1 \mathrm{~km}$ radius of the primary ice core drilling facility but avoided regions disturbed by camp operations or the "drift tail" of enhanced accumulation downwind of the camp. Following prior practice (e.g., Benson, 1962; Koerner, 1971; Alley, 1988), each sampling site involved excavating a pair of $\sim 2 \mathrm{~m}$ cubic pits separated by a wall $\sim 0.5 \mathrm{~m}$ 
Table 1. Field observation table (see also Figs. 5-8).

\begin{tabular}{llllll}
\hline Field Season & Observation Window & $\begin{array}{l}\text { Observation } \\
\text { duration }\end{array}$ & AWS & Other Instrumentation & Pit \\
\hline $2008-2009^{\mathrm{a}}$ & 12 Dec 2008:10 Jan 2009 & $\sim 29$ days & - & - & $\times$ \\
$2009-2010^{\mathrm{a}}$ & 27 Dec 2009:25 Jan 2010 & $\sim 29$ days & $W, H, T$ & - & $\times$ \\
$2010-2011$ & 20 Dec 2010:9 Jan 2011 & $\sim 20$ days & $W, H, T$ & - & $\times$ \\
$2011-2012^{\mathrm{a}}$ & 25 Dec 2011:4 Jan 2012 & $\sim 12$ days & $W, H, T, I$ & Dual LI-COR LI200 sensors & $\times$ \\
$2012-2013^{\mathrm{a}}$ & 18 Dec 2012:30 Dec 2012 & $\sim 12$ days & $W, H, T, I$ & $\begin{array}{l}\text { Kipp \& Zonen CNR2 sensor } \\
\text { Shallow PRD strings }\end{array}$ & $\times$ \\
& & & & & \\
\hline
\end{tabular}

$W, H, T, I-$ Wind, Humidity, Temperature, Insolation. ${ }^{\mathrm{a}}$ Fegyveresi (2015), ${ }^{\mathrm{b}}$ Muto et al. (2011)

thick, with one pit left open to supply backlight and the other a roofed observation pit. Features such as crusts and hoar layers were easily identifiable from the observation pit on the backlit wall (Fig. 2). Pit walls were observed, mapped, sampled, and photographed (tripod-mounted, $>1 / 4 \mathrm{~s}$ exposures). Each pit was oriented so the prevailing wind direction, approximately north-south, ran from right to left along the backlit wall.

An AWS on site at WAIS Divide (named Kominko-Slade in the University of Wisconsin AWS system; Lazzara et al., 2012), collected data on temperature, air pressure, wind, and humidity starting in the 2009-2010 season (all dates and times are GMT). Beginning in 2011-2012, upwardfacing and downward-facing shortwave LI-COR LI200 pyranometers were added initially $1 \mathrm{~m}$ above the surface to measure incoming and outgoing shortwave radiation (0.4$1.1 \mu \mathrm{m}$ spectral response). Both sensors were newly calibrated and mounted in a cosine-corrected head (for solar angles up to $80^{\circ}$ ), with typical operational errors in daylight of $\pm 3 \%(\max \pm 5 \%)$. A Kipp \& Zonen CNR2 net radiometer with upward- and downward-facing pyranometers and pyrgeometers was added on an AWS mounting arm during the 2012-2013 season, in order to measure both net shortand longwave radiation. This instrumentation replaced the previous LI-COR instrumentation. The pyranometers operated with a spectral response of $0.3-2.8 \mu \mathrm{m}$, operational errors of $\pm 3.5 \%$, and sensitivity of $15.21 \mu \mathrm{V} \mathrm{W}^{-1} \mathrm{~m}^{-2}$, while the pyrgeometers operated with a spectral response of 4.5$45 \mu \mathrm{m}$, operational errors of $\pm 5.6 \%$, and a sensitivity of $12.52 \mu \mathrm{VW}^{-1} \mathrm{~m}^{-2}$; typical impedances were $\sim 7 \mathrm{ohms}$. All AWS relative humidity values reported here are expressed in terms of saturation vapor pressure over ice and corrected for low-temperature offsets (see Anderson, 1994).

Also during the 2012-2013 season, we calibrated and installed five PRD (platinum resistance detector) strings in the upper $5 \mathrm{~m}$ of snow in a $2 \mathrm{~km}$ survey line extending approximately upwind (grid west, true north) starting $\sim 50 \mathrm{~m}$ from the on-site AWS. The strings were designed by one of us (Atsuhiro Muto) following the procedures in Muto et al. (2011). Each sensor string was $5 \mathrm{~m}$ long and consisted of 16 individual PRDs (HEL-700 series; $\pm 0.03^{\circ} \mathrm{C}$ accuracy, $\pm 0.18^{\circ} \mathrm{C}$ to- tal combined error, including data-logger error) with denser sampling in the shallower snow to capture the greater variability there (see also Supplement Table S2). Sensor calibration took place over a $60 \mathrm{~min}$ period using a constantly stirred ice-bath method, and then the newly calibrated sensors were deployed incrementally over a 10-day period starting 15 December. Deployment boreholes were drilled using a $4 \mathrm{~cm}$ diameter hand auger and then back-filled once strings were installed. Campbell logging equipment (CR1000 data logger and AM/16/32 Multiplexer) and $12 \mathrm{~V}$ sealed lead-acid batteries were housed in a foam-insulated wooden box beside each borehole and just below the surface. The first string was placed $50 \mathrm{~m}$ from the AWS, and the other strings were placed upwind of it by 10, 100, 1000, and $2000 \mathrm{~m}$ (Table S3). Measurements were taken every minute over the survey interval. Each $12 \mathrm{~V}$ battery was swapped out weekly with newly charged replacements to ensure that the sensor strings were continually recording. During each site visit, we took photographs and noted local meteorological and surface conditions. Each sensor string took approximately $24 \mathrm{~h}$ to equilibrate with the surrounding snow following installation due to the backfilling of the open boreholes with surface snow.

We studied crusts in the ice core as well as near the surface. As described in Fitzpatrick et al. (2014), the entire deep core and various associated shallower cores were inspected visually during core processing lines at the US National Ice Core Laboratory, primarily by one of us (Matthew K. Spencer), but with some intercomparisons from other observers. The core was observed on a light table in a darkened booth, and key features were noted on meter-length log books. The crusts were easily visible as thin, glassy, bubblefree or nearly bubble-free layers (e.g., Fig. 1).

Annual cycles are visible in the bubbly part of the core, arising from the tendency for near-surface processes to generate coarse-grained, low-density layers including depth hoar in summer (Fitzpatrick et al., 2014; Fegyveresi, 2015). However, annual-layer dating of the ice core using electrical conductivity (ECM, which is primarily controlled by ice chemistry) and soluble-ion chemistry proved more accurate than dating with visible strata (Buizert et al., 2015; Sigl et al., 2016; WAIS Divide Project Members, 2013). Here, we es- 

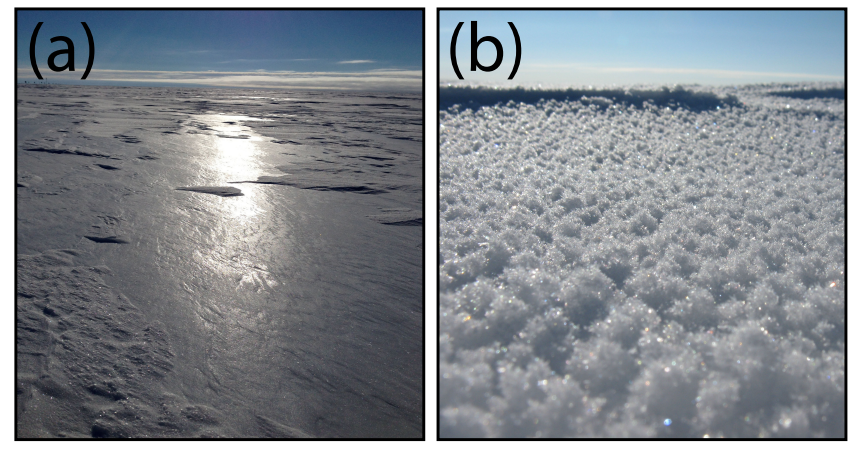

Figure 3. Surface "glaze" (a) that formed on a calm, sunny day (23 December 2012) at WAIS Divide, and the subsequent surface hoar layer (b) that formed on its surface after several calm days.

timate the season in which each crust occurs by assigning each summertime peak in the WD2014 timescale to 1 January of its year and then linearly interpolating; accumulation at the site is relatively evenly distributed through the year, justifying this approximation (Banta et al., 2008; Fegyveresi, 2015; Fegyveresi et al., 2016).

\section{Observations}

\subsection{Near-surface observations}

We summarize key observations on crust formation here. Additional information, and complete narrative descriptions of particular crust-forming episodes, are provided in $\mathrm{Fe}$ gyveresi (2015).

Glazed crusts were repeatedly observed to form on the snow surface (Figs. 3 and 4), primarily during late December and January, with an interval between formation events of roughly 1 and 2 weeks (see Figs. 5-8). Crust formation often followed a storm or wind event and occurred during a time of higher atmospheric pressure, light winds, clear sky, strong insolation, large diurnal temperature cycling, and low relative humidity.

As shown in Fig. 9, the crusts were often internally complex. The upper few millimeters of the surface snow were anomalously high-density $\left(>400 \mathrm{~kg} \mathrm{~m}^{-3}\right)$ and fine-grained, and might be termed a multi-grain crust. Within this, and especially at the top, were one or more lower-porosity singlegrain crusts. To an observer, light reflected off these crusts gave the appearance of a glaze on the snow surface (e.g., Fig. 4) (see also Orsi et al., 2015, their Fig. 5).

Typically, a glazed crust started as isolated sub-meter to few-meter patches on unshaded regions of the snow surface or sastrugi, which were most consistently exposed to sunlight, and spaced tens of meters to more than $100 \mathrm{~m}$ apart. The spatial size and extent of glazed crust patches varied considerably and were not measured directly; however, no single observed crust patch was greater than $100 \mathrm{~m}$ in length in any

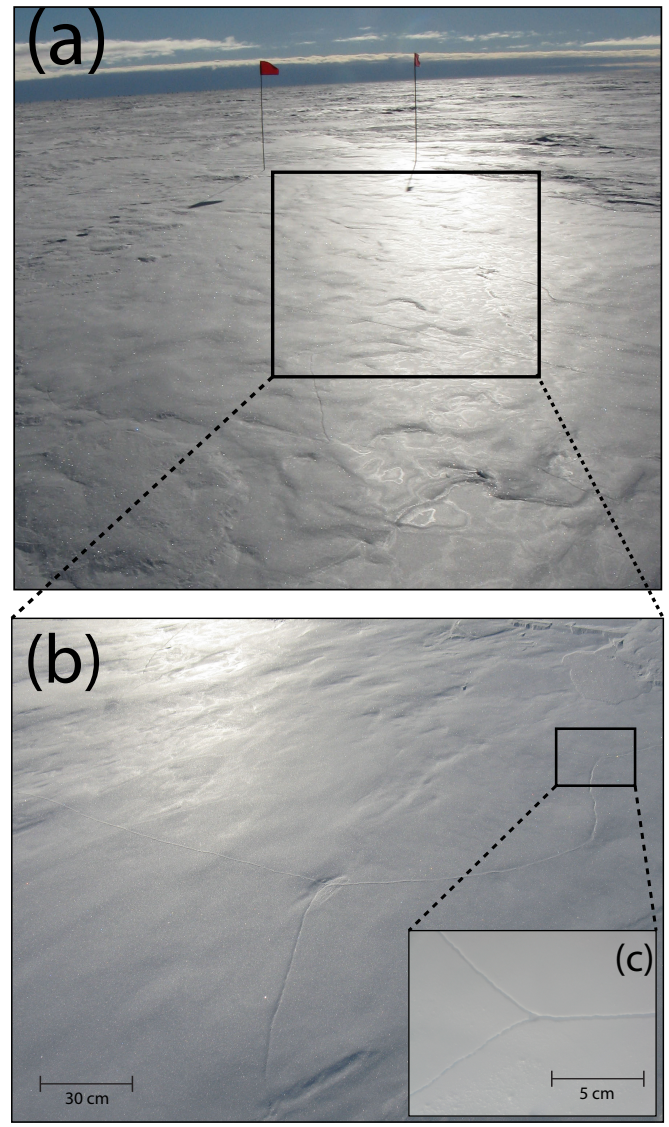

Figure 4. Surface "glaze" seen at the WAIS Divide site (a). A zoomed-in view shows the polygonal cracking that initiates at the surface from thermal contraction, following several sunny, clear-sky days (b). Closer inspection reveals greater detail and scale of a crack triple junction (c).

dimension. Over the first days of formation, glazed crusts expanded to form a laterally extensive interconnected surface broken by isolated sub-meter to few-meter unglazed patches on shaded faces of sastrugi. Glazed crusts were most continuous where the surface was smoothest. Reconnaissance surveys extending a few kilometers from camp showed that glazed-crust formation was consistent at least that far.

Within 2-3 days of formation, glazed features developed prominent polygonal cracks with few-meter spacing (e.g., Fig. 4). It is likely that these cracks formed by thermal contraction during nighttime cooling, which was driven by the large diurnal temperature swings observed at the time (see below). We excavated some cracks, which could be traced downward from the surface typically $\sim 20-30 \mathrm{~cm}$.

A pronounced hoar began forming within $24 \mathrm{~h}$ of the onset of cracking of the glazed crust in each case observed (e.g., Fig. 3). Measured relative humidity was notably higher during hoar formation (see Figs. 5-8) than before, and sometimes (e.g., 7 January 2010) a fog developed early during hoar formation, providing a source of vapor to the surface 


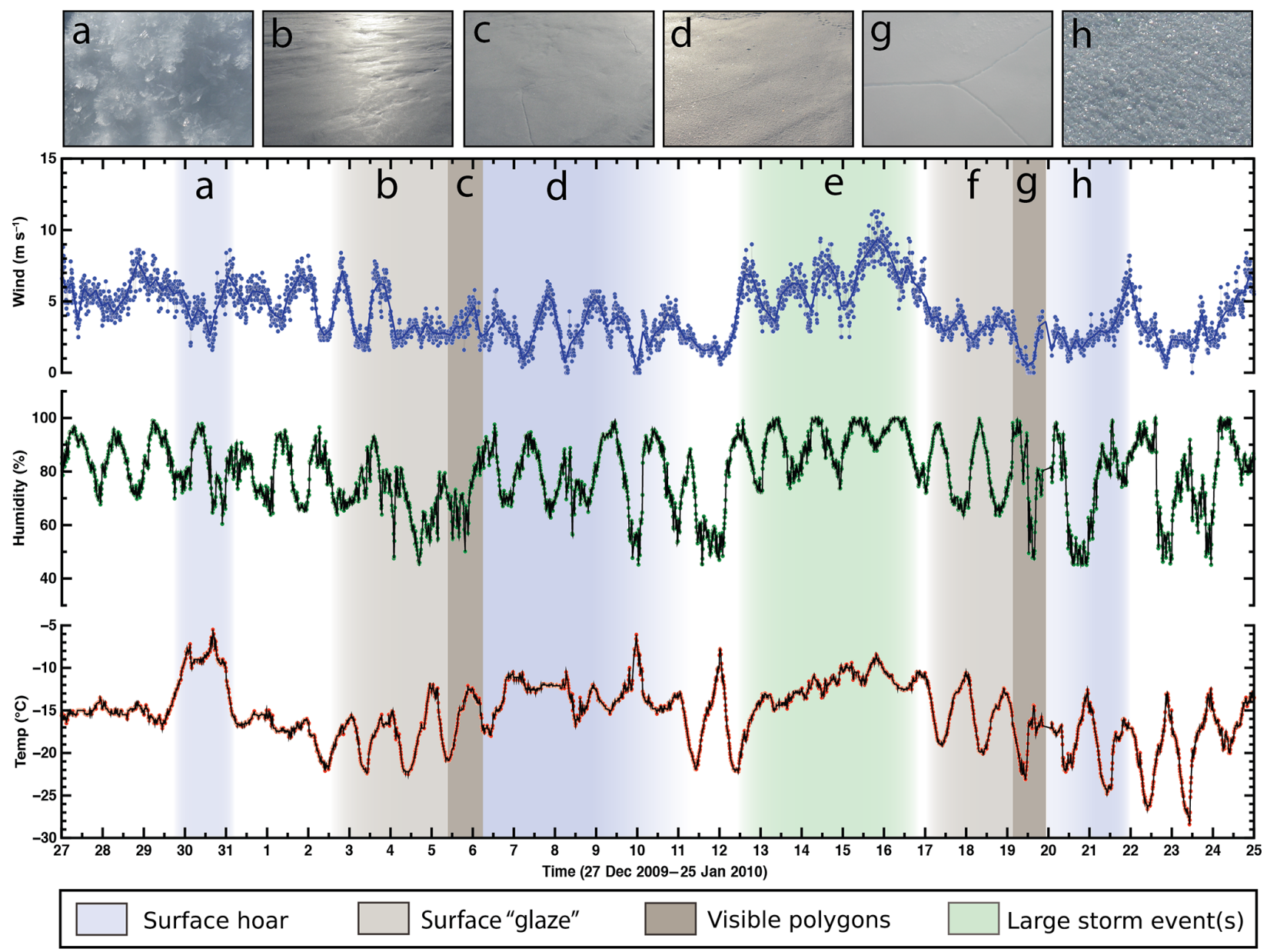

Figure 5. Surface evolution over 29 days in the 2009-2010 season, and AWS data. Shading shows episodes of surface hoar, glazes, and polygonal cracking; storm events are also shown. Letters near the top refer to photographs above of specific features or events. All dates and times are GMT (WAIS local time $-12 \mathrm{~h}$ ). The errors for all AWS instruments are listed in Table S1.

hoar from above. Surface glazing was not required for formation of such hoar layers, as one formed quickly on $30 \mathrm{De}-$ cember 2009 during a very warm $\left(>-10^{\circ}\right)$ fog episode with elevated measured relative humidity, but without prior formation of surface glaze.

Hoar layers that we observed during the field seasons were subsequently buried, destroyed by wind, or gradually sublimated away over 2-3 additional days. We observed strong winds remove hoar layers, with a threshold of $\sim 7 \mathrm{~m} \mathrm{~s}^{-1}$ ( $\sim 13$ knots). In one case, hoar removal required somewhat lower speed when wind was directed orthogonal to the prevailing direction and thus sastrugi orientation, similar to observations by Champollion et al. (2013) at Dome C, East Antarctica.

No above-freezing temperatures were observed by the AWS, but on 2 January 2011 the temperature reached a high of $-2.8^{\circ} \mathrm{C}$ (see Fig. 6; Supplement Fig. S1). While no direct surface melt was observed, some melt was noted along exposed, vertically cut wall faces near the ice core drilling facility (Fig. S2). A prominent multi-grain crust was ob- served the next year in snow pits, likely dates from that time, and shows features that are consistent with some meltingrefreezing having occurred (Fig. S3).

The PRD strings document strong variations in subsurface temperature, following the air temperatures as expected. During the cooling phases of diurnal cycles, air temperatures (AWS) and near-surface snow temperatures (S0) dropped well below temperatures deeper in the snow, including the shallowest in-snow sensor (S1) at $\sim 20 \mathrm{~cm}$ (Figs. 10 and 11), with the surface as much as $3{ }^{\circ} \mathrm{C}$ colder than snow at $40 \mathrm{~cm}$ (S2) depth (e.g., Fig. S4). This would have driven upward mass flux from the deeper snow towards the surface. Such conditions often developed when surface hoar was forming from fog, and thus likely with a downward as well as an upward vapor source to the near-surface layer.

\subsection{Snow pit observations}

Each of the five snow pits showed a clear annual cycle in the visual stratigraphy, but with notable "noise". Depth hoars 


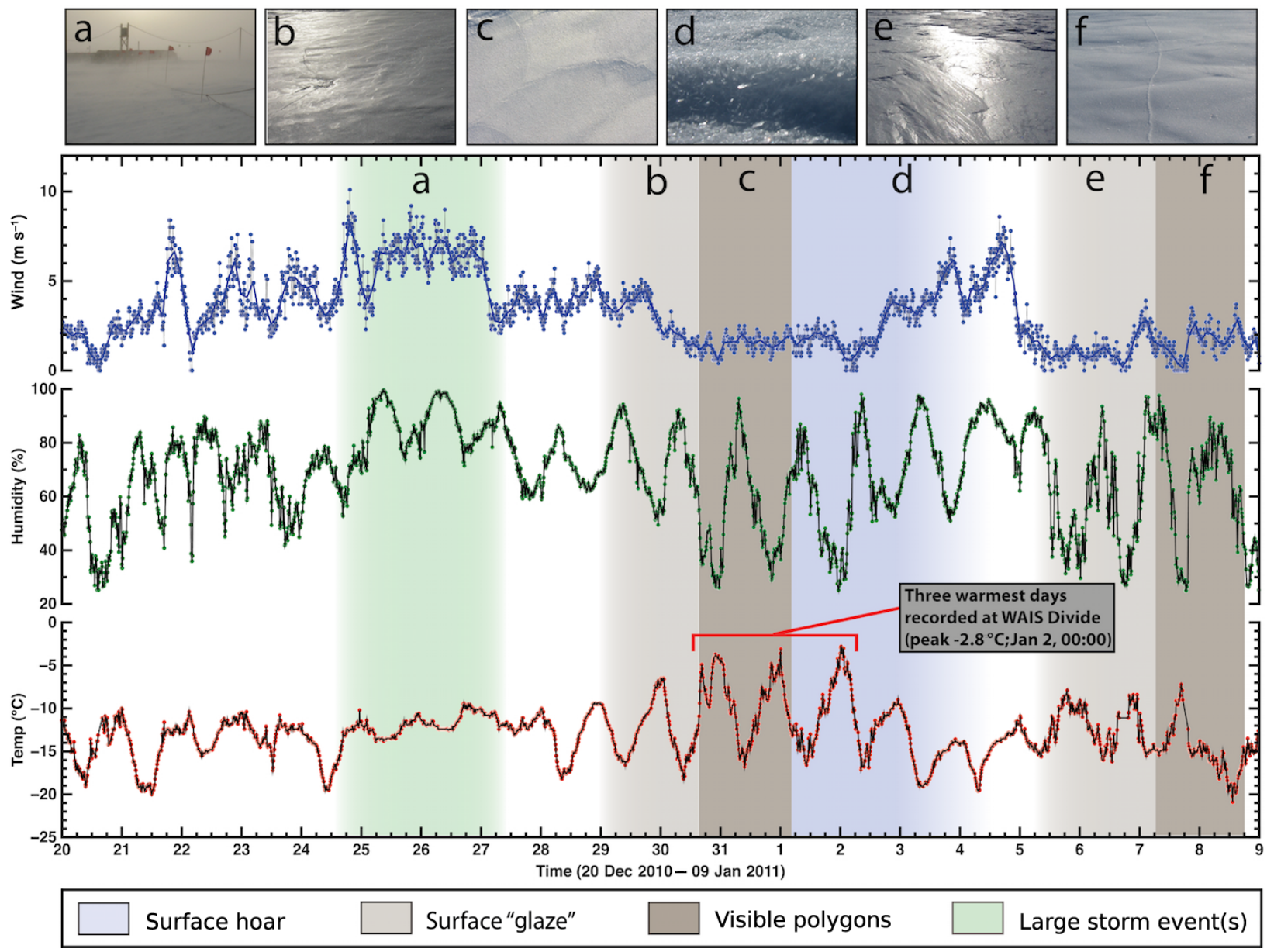

Figure 6. Surface evolution over 20 days in the 2010-2011 season, and AWS data. Shading shows episodes of surface hoar, glazes, and polygonal cracking; storm events are also shown. Letters near the top refer to photographs above of specific features or events. All dates and times are GMT (WAIS local time $-12 \mathrm{~h}$ ). The errors for all AWS instruments are listed in Table S1.

occurred primarily in summertime layers and into autumn, but with occasional hoar layers in winter and spring layers. Crusts were also most common in summertime and into autumn, but not restricted to those times. Similar to the observations made by Alley (1988) at other sites in Antarctica, sequences of strata at WAIS Divide typically showed lateral continuity over $2 \mathrm{~m}$ scales, although with some variation. Many graded beds were also present, likely indicative of changes during a specific storm event or primarily before the next storm. This was later confirmed on site with accumulation stakes and measurements following specific large storm events (see also Koffman et al., 2014; Criscitiello et al., 2014).

The snow pits from the 2008-2009, 2009-2010, and 2010-2011 seasons at WAIS Divide were mapped here in greatest detail, and meter-wide sub-swaths of their complete pit wall maps are shown in Fig. 12. Complex stratigraphy and variations are clearly discernable and illustrate the variability within $1 \mathrm{~km}$ of each other at WAIS Divide in contiguous years. This is likely indicative of the influence of complex processes of deposition and metamorphism, with frequent occurrences of depositional and erosional features (sastrugi, whalebacks, wind scoops, hollows, etc.). We chose annual layers in the pit maps based upon visual inspection in the field, subsequent examination of photographs of the pits, and overall trends in measured densities (see, e.g., Fig. 13).

We measured pit bulk densities using $100 \mathrm{~cm}^{3}$ stainlesssteel, box-type cutters (e.g., Conger and McClung, 2009) and a digital scale accurate to $0.1 \mathrm{~g}$. Density samples were taken in all five concurrent seasons' pits in duplicate, at $\sim 5 \mathrm{~cm}$ intervals, from the pit side wall (so as not to disturb the backlit wall). These duplicates were then averaged together for final values. Samples measured in the 2008-2009 pit were taken with regards to marked strata, and therefore at a slightly higher frequency. Density measurements from pits of all five seasons yielded an average density of $386.6 \pm 3.2 \mathrm{~kg} \mathrm{~m}^{-3}$ for the upper $2 \mathrm{~m}$ of snow (Fig. 14), all with a nearly identical linear trend-line slope of $\sim 0.4 \mathrm{~kg} \mathrm{~m}^{-3} \mathrm{~cm}^{-1}$ with depth.

Seasonal interpretations of all five pits indicated an average of $\sim 3.75$ years of accumulation recorded over the 

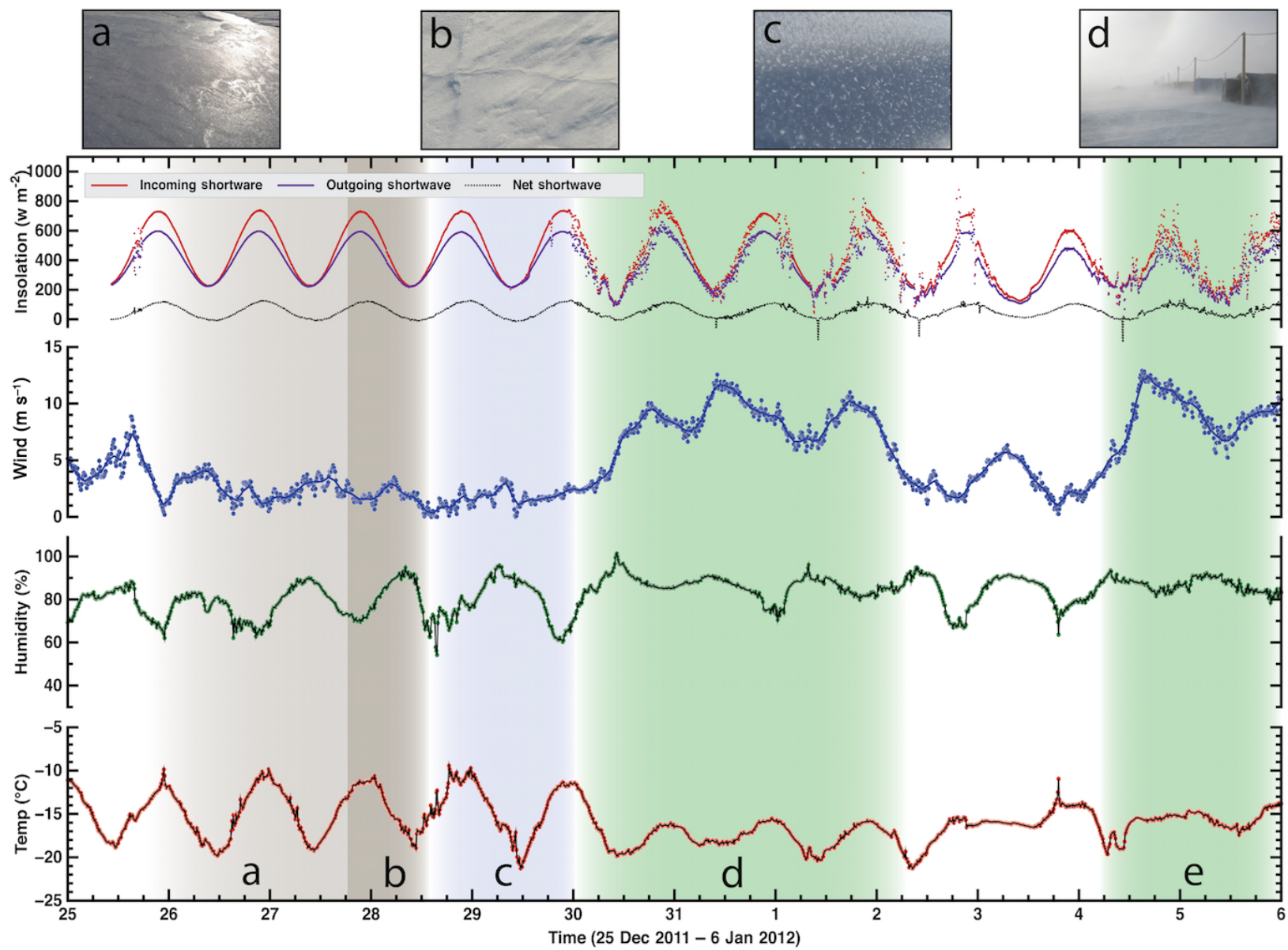

Surface hoar

Surface "glaze"

Visible polygons

Large storm event(s)

Figure 7. Surface evolution over 12 days in the 2011-2012 season, and AWS data. Shading shows episodes of surface hoar, glazes, and polygonal cracking; storm events are also shown. Letters near the top refer to photographs above of specific features or events. All dates and times are GMT (WAIS local time $-12 \mathrm{~h}$ ). The errors for all AWS instruments are listed in Table S1.

$2 \mathrm{~m}$ depths, which yields an average of $\sim 0.53 \mathrm{ma}^{-1}$ of accumulation at the average pit snow density. When converted to water equivalent, this becomes $\sim 0.20 \mathrm{ma}_{\text {w.e. }}^{-1}$ (or $\sim 0.22 \mathrm{ma} \mathrm{a}_{\text {ice }}^{-1}$ ). These values agree closely with recently published values (WAIS Divide Project Members, 2013; Banta et al., 2008; Burgener et al., 2013).

We documented obvious crusts and hoar layers for each snow pit. Most commonly, crusts occurred just above depth hoars, but crusts were observed without hoar, and hoar without crust. Both single-grain-thick $(\sim 1 \mathrm{~mm})$ and multi-grain $(\geq 4 \mathrm{~mm}$ ) crusts were observed, with the common association of single-grain crusts in and usually at the top of multigrain crusts as noted above. All crusts had densities estimated over $400 \mathrm{~kg} \mathrm{~m}^{-3}$. When a multi-grain crust containing a single-grain crust is counted as one feature, the five $2 \mathrm{~m}$ snow pits revealed an average of $\sim 18.8 \pm 2.5( \pm 1 \sigma)$ total crusts, or approximately 5 crusts year ${ }^{-1}$.

\subsection{Ice core data}

In the bubbly ice included in our crust logging (120-577 m depth) in the WAIS Divide core, 10268 crusts were identified (Fig. 15). A few were discontinuous across the core, or displayed at least a few pores extending through; others appeared largely or completely continuous and impermeable at the scale of the core. Experience with independent observers showed little or no error in crust identification. We cannot rule out the possibility that bubble migration contributed to loss of some crusts in the deepest bubbly ice considered, but the crusts continued to be clear and readily identifiable, so we do not believe that the trend to fewer crusts in the deepest ice is an artifact. We cannot fully exclude the possibility that there is an observational bias related to the drop in crust prevalence over the most recent $\sim 250$ years, as the crusts are more difficult to discern in the shallow firn and snow. 


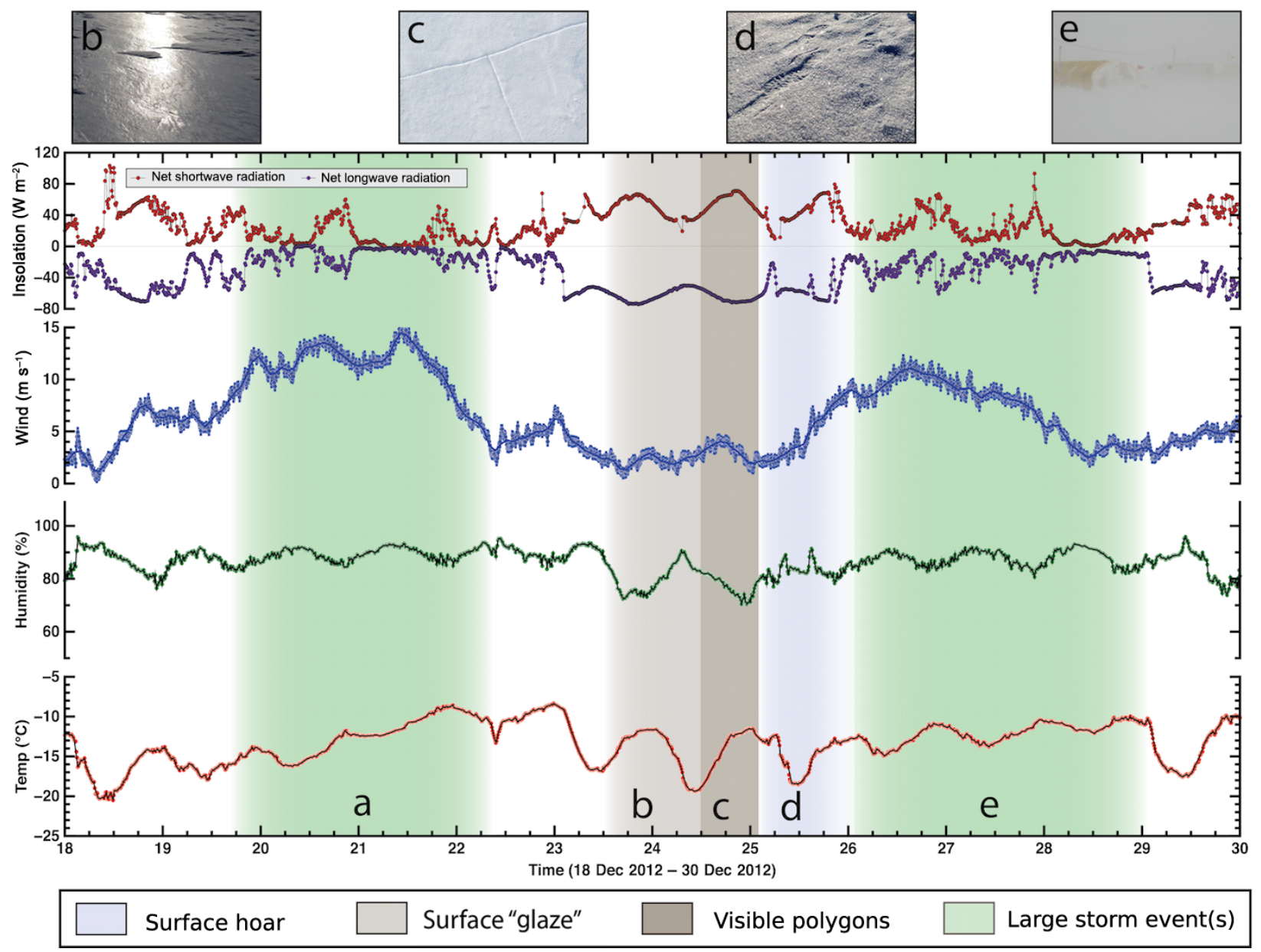

Figure 8. Surface evolution over 12 days in the 2012-2013 season, and AWS data. Shading shows episodes of surface hoar, glazes, and polygonal cracking; storm events are also shown. Letters near the top refer to photographs above of specific features or events. All dates and times are GMT (WAIS local time $-12 \mathrm{~h}$ ). The errors for all AWS instruments are listed in Table S1.

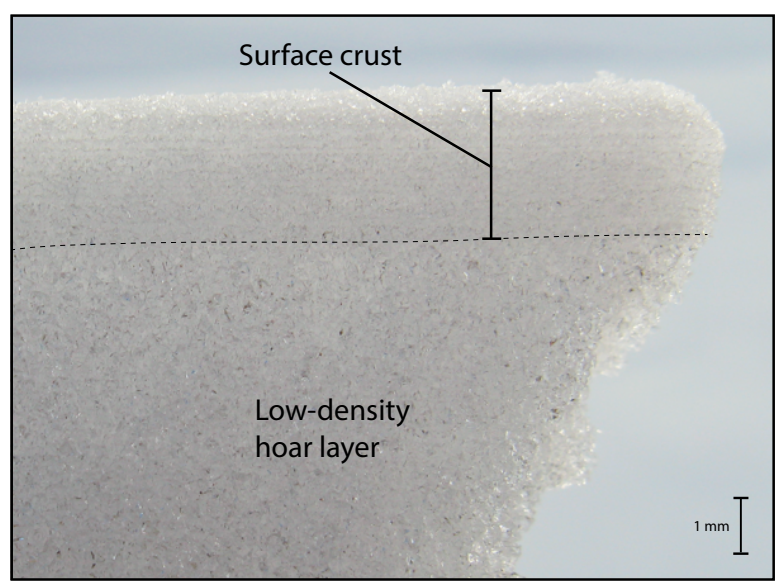

Figure 9. A surface snow sample excavated from a glazed area at WAIS Divide before the onset of polygonal cracking, showing a couplet of an evolved $\sim 3 \mathrm{~mm}$ high-density $\left(>400 \mathrm{~kg} \mathrm{~m}^{-3}\right)$, multi-grain surface crust containing single-grain crusts and overlying a lower-density $\left(<300 \mathrm{~kg} \mathrm{~m}^{-3}\right)$ hoar layer.
The seasonal distribution of the crusts is shown in Fig. 16. Crusts occur year-round but are $\sim 45 \%$ more frequent in summertime accumulation than in wintertime. Certainly, the natural variability in seasonal distribution of snow accumulation and in the timing of peak impurity input means that details of the shape of the seasonal distribution of crust occurrence are notably uncertain. However, given the high reliability of the annual-layer dating, and the multiple indicators that agree well (Buizert et al., 2015; Sigl et al., 2016; WAIS Divide Project Members, 2013), "summer" vs. "winter" or "nonsummer" is well-constrained.

Time trends of seasonal crust occurrence are also shown in Fig. S5, separating the largely sunless winter (May-August) from the sunny spring, summer, and fall (September-April, with at least $8 \mathrm{~h}$ of sunlight per day). Both first increase and then decrease slightly over the 2400 -year record, but with a larger relative change in the sunlight season. 

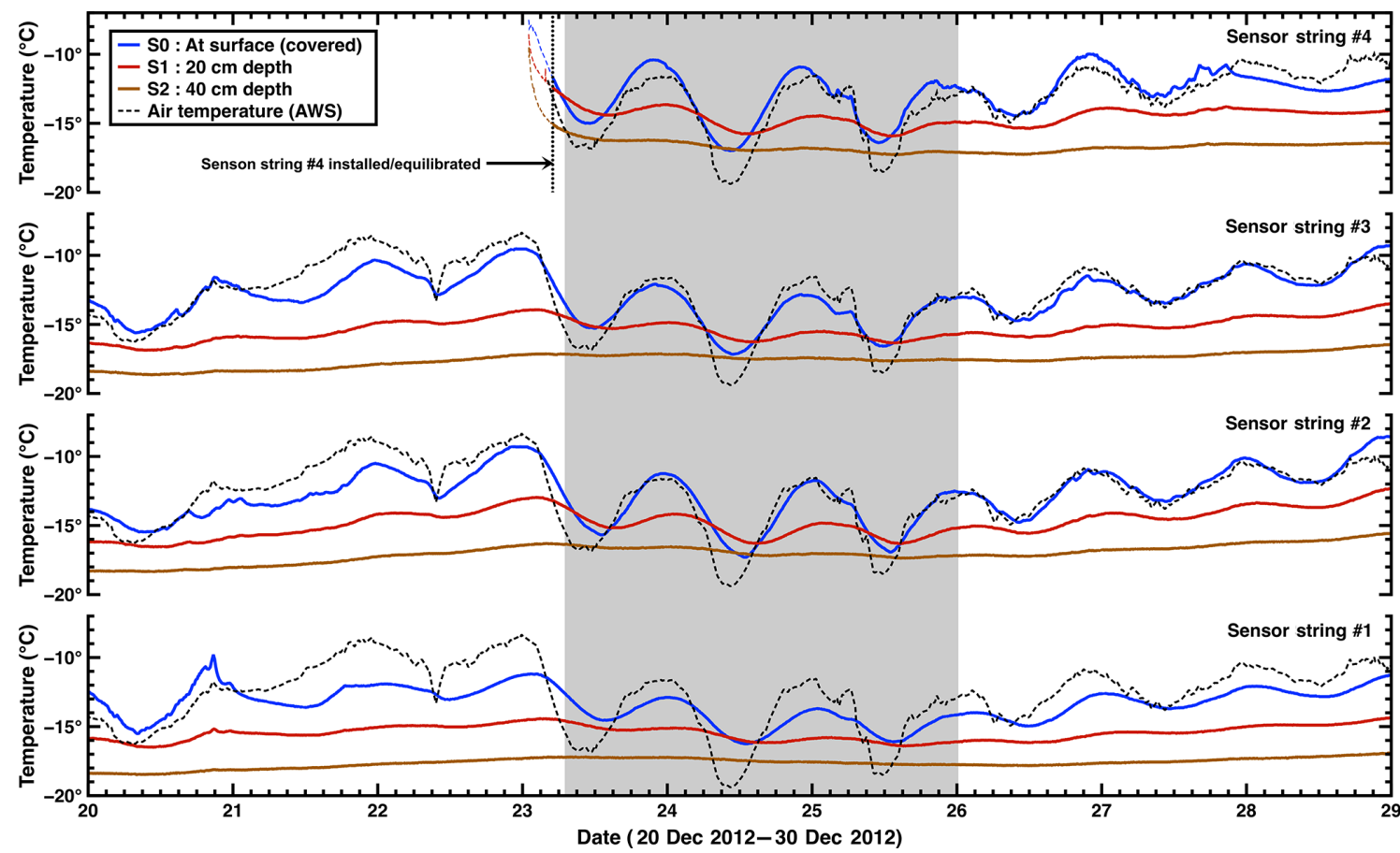

Figure 10. Temperature measurements (1 min interval) in snow from the 2012-2013 season, from the uppermost three PRDs (surface down to $40 \mathrm{~cm}$ ). Data are from the four sensor stations closest to the station. The shaded area corresponds to an episode of glaze and hoar growth (see Fig. 8). Distinct near-surface temperature inversions occurred each night during this 3-day period (see Fig. 11). Sensor \#4 was not installed until 22 December and therefore did not equilibrate until early on the 23 December as indicated. Air temperature is also shown as recorded by the AWS (errors listed in Table S1). The AWS temperature sensor is located $\sim 1 \mathrm{~m}$ above the snow surface. All dates and times are GMT (WAIS local time $-12 \mathrm{~h}$ ).

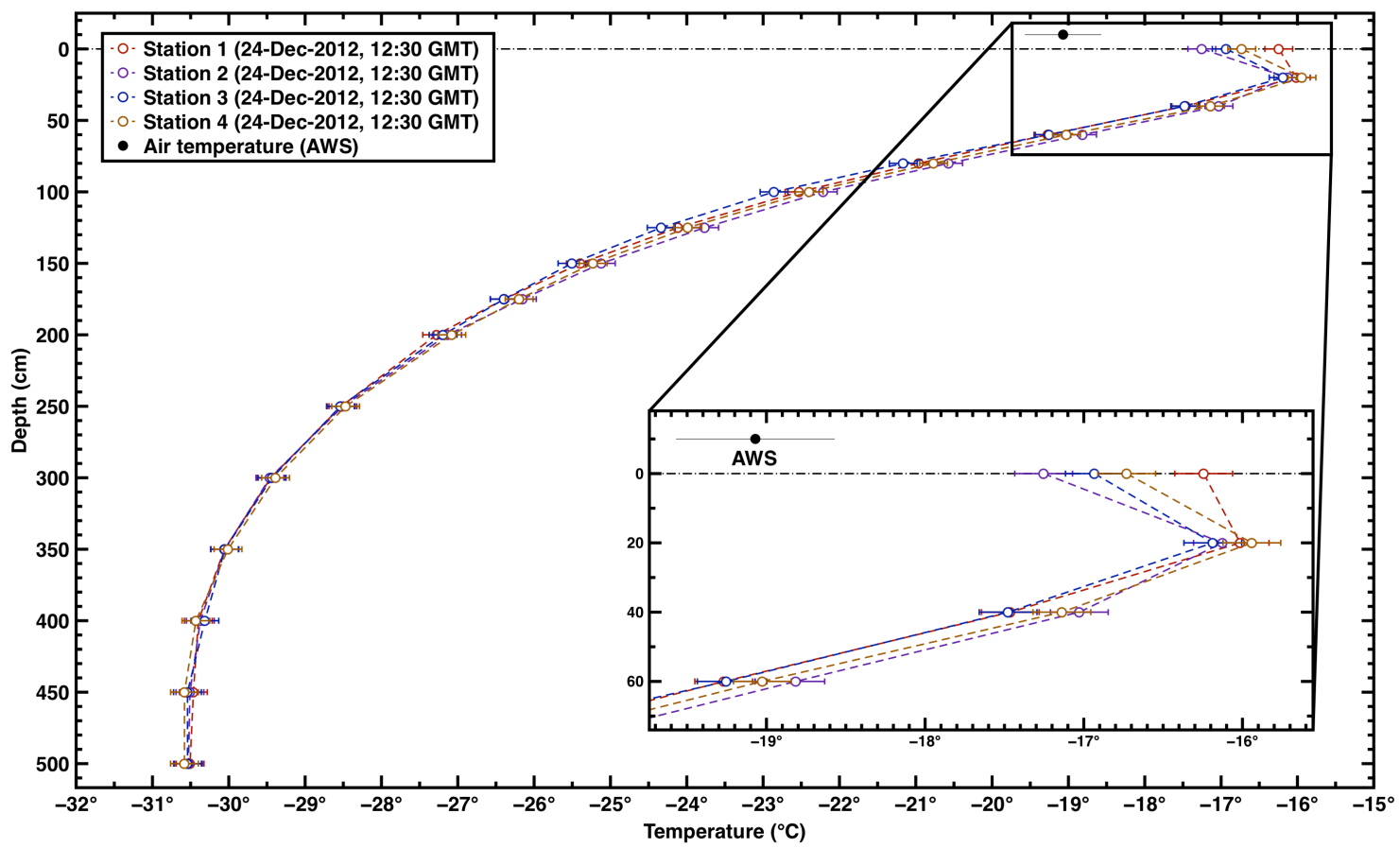

Figure 11. Snapshot temperature readings for PRD-string stations \#1-4, taken on 24 December 2012 at $\sim 12: 30$ GMT, showing the temperature inversion with colder air (AWS data) and upper surface over warmer near-surface snow. 

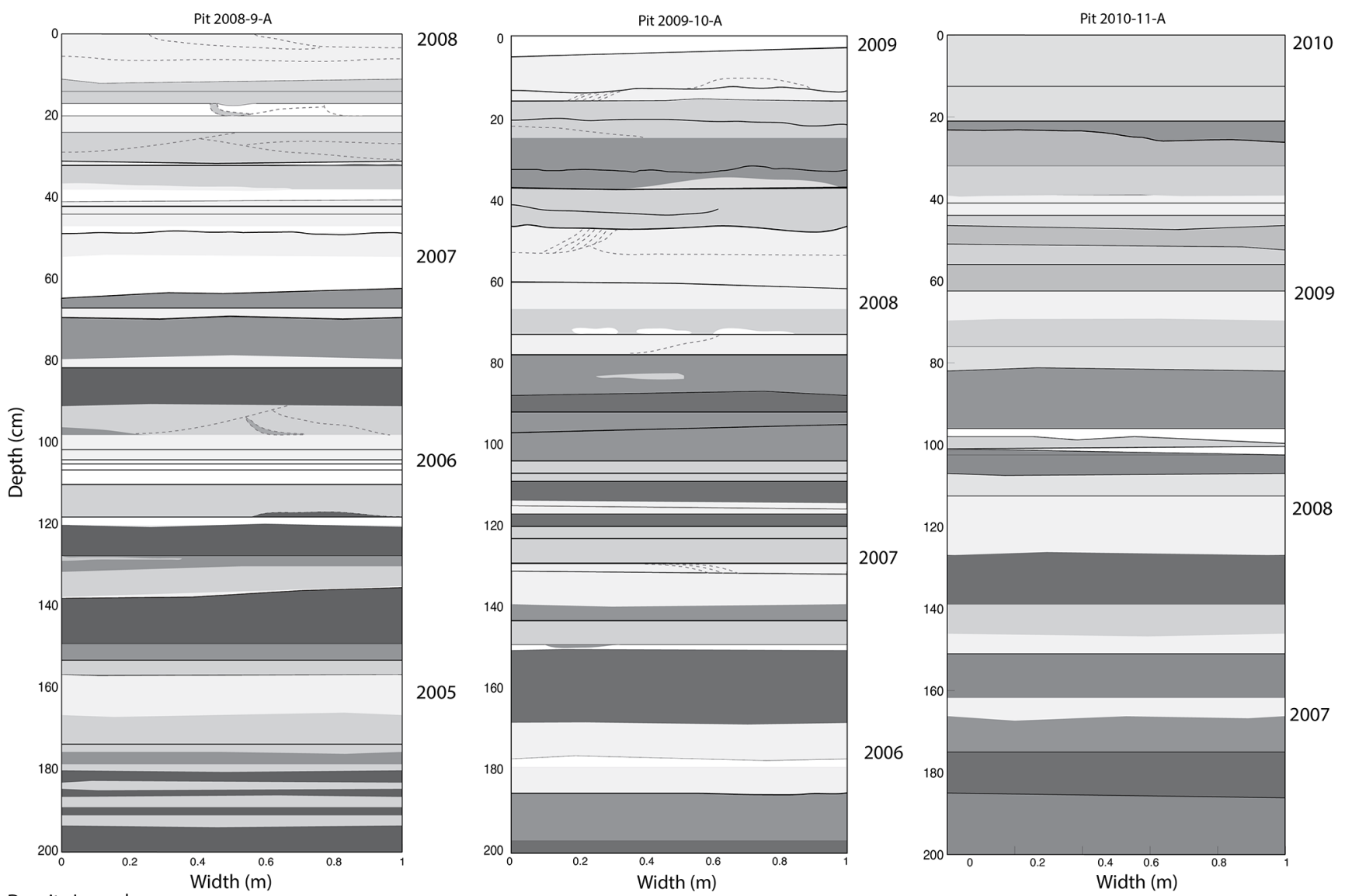

Density legend

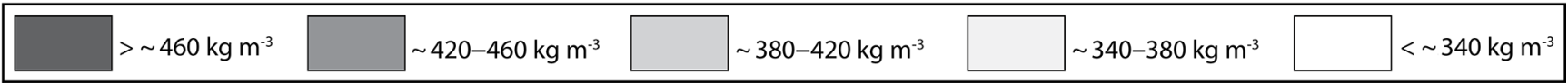

Figure 12. Complete wall maps of backlit snow pits prepared during 2008-2009, 2009-2010, and 2010-2011 WAIS Divide field seasons. Layering and density contrast are noted by degree of shading. Fine- to medium-grained, higher-density snow layers are shown with darker grey coloring, whereas coarse-grained and low-density layers (e.g., depth hoar) are shown in white. Crusts are indicated with solid lines, while dotted lines are used to represent cross-bedding at depth. Years were identified based on approximate depths of peak summers and the average measured densities. The pit wall surfaces trend in parallel with the prevailing wind direction at WAIS Divide (approximately north-south, with north to the right).

\section{Synopsis and discussion}

Our observations confirm and extend prior work on this topic (see, e.g., Anderson and Benson, 1963). Depositional processes and metamorphism primarily in the upper few centimeters of near-surface snow produce prominent layering. Wintertime accumulation, while notably variable, is more homogeneous than summertime deposits, with wind-packed layers prominent in winter and more-variable layers including crusts and hoar more common in summer (e.g., Sorge, 1935; Benson, 1962; Gow, 1965, 1969; Weller, 1969; Colbeck, 1982, 1983; Alley, 1988; Alley et al., 1997). These features are altered during subsequent burial and conversion to bubbly ice but still produce recognizable features in the ice core that allow identification of annual layers and crusts (e.g., Alley et al., 1997; Fitzpatrick et al., 2014).
Our observations at WAIS Divide show repeating events that generate the main features of the summertime accumulation. In a typical event, a storm with strong winds brings snow accumulation, followed by a high-pressure system bringing clear skies, greatly reduced winds, initially low humidity, and strong diurnal variations in sunshine, air temperature, and net surface energy balance.

Early in this clear-sky interval, the wind-packed upper surface develops a millimeter-thick glazed crust or possibly crusts in a few-millimeters-thick multi-grain crust. Strengthening of crusts over one to a few days is followed by polygonal cracking from contraction caused by nighttime cooling. Vapor released through the cracks contributes to rising relative humidity and surface hoar deposition in subsequent nights. At WAIS Divide, evolution of the crust-hoar complex typically is truncated by arrival of another storm, which may 


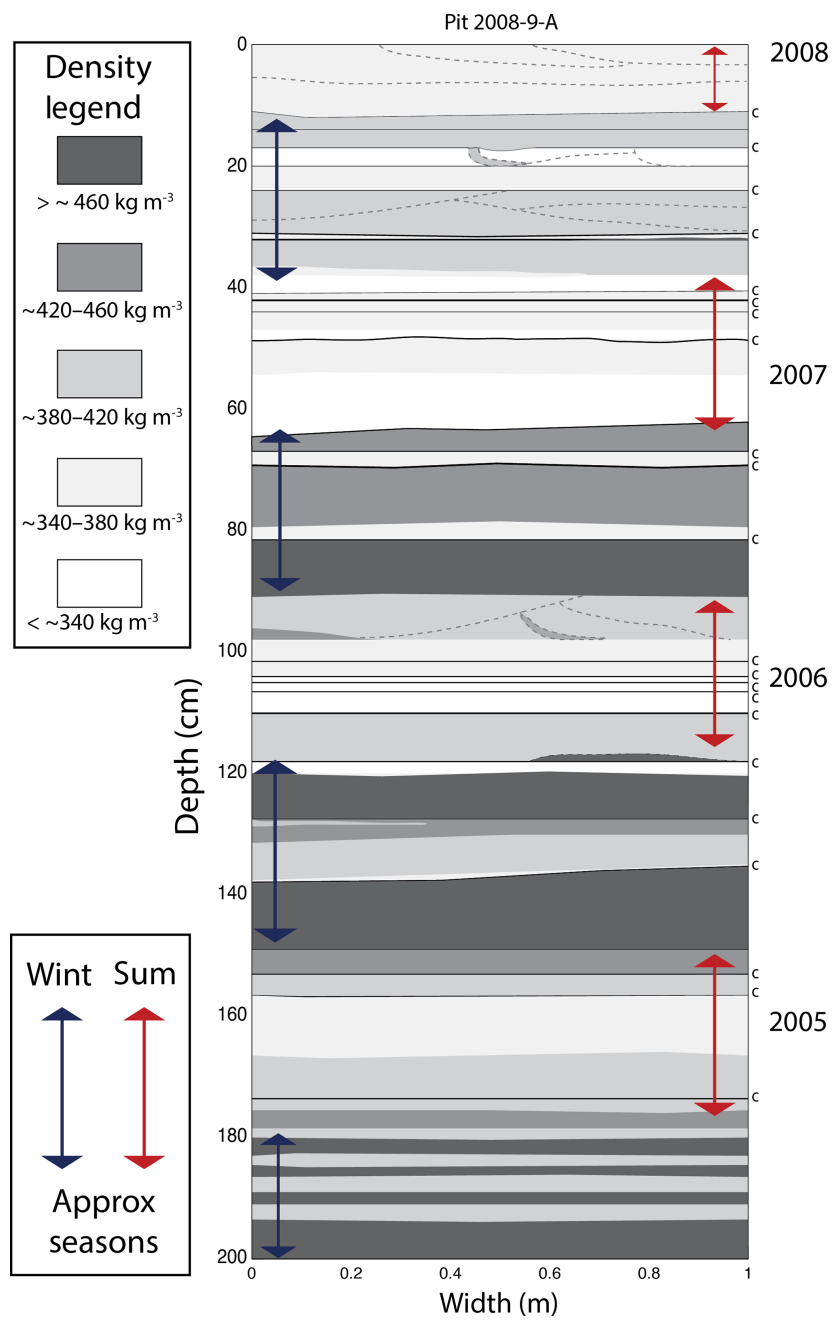

Figure 13. A detailed view of data for snow pit 2008-09-A, including wall map, density profile, annual layer picks, and crust occurrences. Density, layering, and feature preservation are again noted as in Fig. 12. Individual crusts are identified with a labeled "c" along the vertical axis. Seasonal accumulation layers were "picked" visually in the pit (shown with red and blue arrows). These observations indicate a somewhat regular pattern of equally distributed yearly accumulation at WAIS Divide with clear annual signals.

remove or bury the hoar, and typically buries the crusts below the level of fastest metamorphism, allowing them to be preserved.

Not every aspect of a typical event is observed in each case. Crusts form and can be buried by additional snowfall without growth of a surface hoar on top of them. Crusts are somewhat discontinuous, and surface hoar can grow where a crust is absent. And, perhaps most importantly here, a crust that remains near the surface (in the upper few centimeters) for too long may slowly lose mass and cease to be a crust.

Our data provide strong constraints on models of many of the observed processes. Surface hoar grew especially at night when relative humidity was high, sometimes with fog, and with deposition occurring on tent ropes or other surfaces as well as on the snow surface (e.g., Fig. S6), clearly demonstrating a source of vapor from above. Surface hoar typically formed however, when the upper snow surface was colder than layers beneath, indicating a vapor source from below. Hence, our surface hoars included elements of both depositional and sublimation hoar crystals as defined by Gallet et al. (2014) based on observations at Dome C, East Antarctica (with sublimation growth being the dominant process).

The high density of both single-grain and multi-grain crusts, approaching the density of ice for the glassy singlegrained crusts, requires that the density of the crusts increased over time, as wind packing has not been observed to approach these high densities. Crusts form during days when atmospheric humidity is low, however, and thus when mass is not being added from above. We have not observed bulk melting at the site (with the one possible exception noted above), nor do the gas measurements of Orsi et al. (2015) indicate bulk melting, so the density increase must arise from some combination of vapor diffusion from below and surface or volume mass transfer likely involving pseudo-liquid layers (Dash et al., 2006), as discussed next.

The data here show that frequently the upper surface is colder than snow beneath, which will lead to upward mass flux. We lack sub-centimetric resolution in thermometry, but physical understanding indicates that very strong gradients likely develop on the centimeter scale just below the upper surface during rapid nighttime cooling. Physical understanding, the data here, and data from previously published studies indicate that intense sunshine generates a temperature maximum in the snow just below the surface (order of $1 \mathrm{~cm}$ ) especially in low-density, low-thermal-conductivity depth hoar (e.g., Alley et al., 1990; Brandt and Warren, 1993), also contributing to upward vapor transport. Hence, the upper surface is expected to gain mass from below during the crust- and hoar-forming events (Alley et al., 1990). Windy conditions would drive undersaturated air into and out of pore spaces, removing mass, but crusts form during relatively still times. The temperature gradients (and noted inversions) measured here at WAIS Divide (see also Figs. 10 and 11, and Fig. S4) are similar to those observed at GISP2 by Alley et al. (1990) and more than sufficient to move the necessary vapor for crust development.

We hypothesize here that these surface conditions cause mass fluxes that fill in open pores in wind-packed layers at the surface to form glazed crusts. A physical model might be based on the following considerations. The thermal conductivity of ice greatly exceeds that of air, so heat transport in near-surface snow is primarily conductive. Ordinarily, the grain curvature adjacent to pores tends to cause diffusive mass loss, enlarging pores by filling necks between grains or other regions of lower vapor pressure. However, because heat flow is primarily through the grain structure, pores in a surface crust will tend to be colder than interconnected grains when the upper surface is colder than the snow be- 


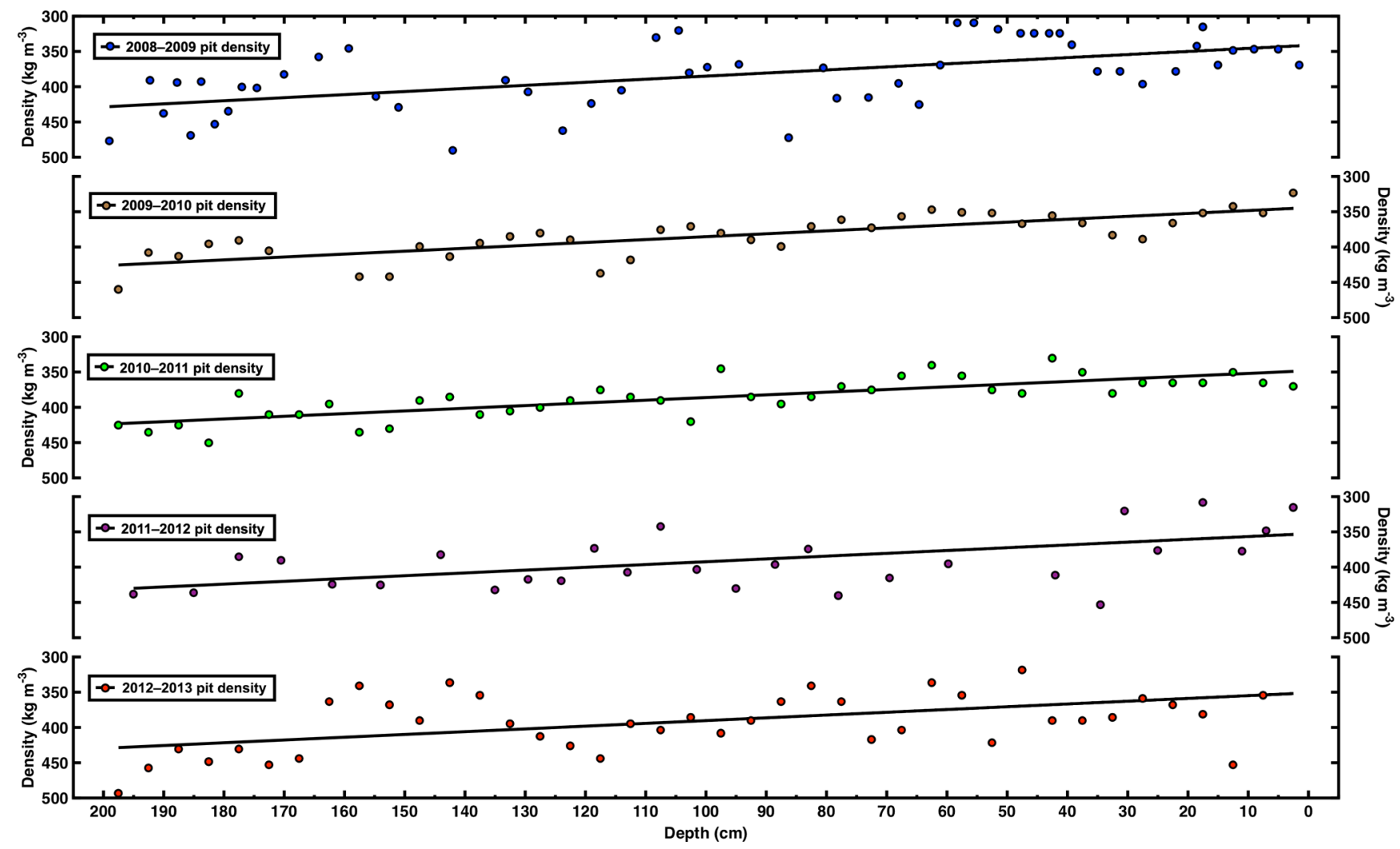

Figure 14. Density profiles measured in snow pits from five concurrent seasons at WAIS Divide (2008-2012). Each pit showed a high degree of sample-to-sample variability as measured densities were widely spaced within the upper $2 \mathrm{~m}$ of snow; estimated annual signals were still identifiable, however. Measurements yielded an overall average density of $386.6 \pm 3.2 \mathrm{~kg} \mathrm{~m}^{-3}$ for the upper $2 \mathrm{~m}$ of snow across all five pits, with nearly identical linear trend-line slopes of $\sim 0.4 \mathrm{~kg} \mathrm{~m}^{-3} \mathrm{~cm}^{-1}$ with depth.

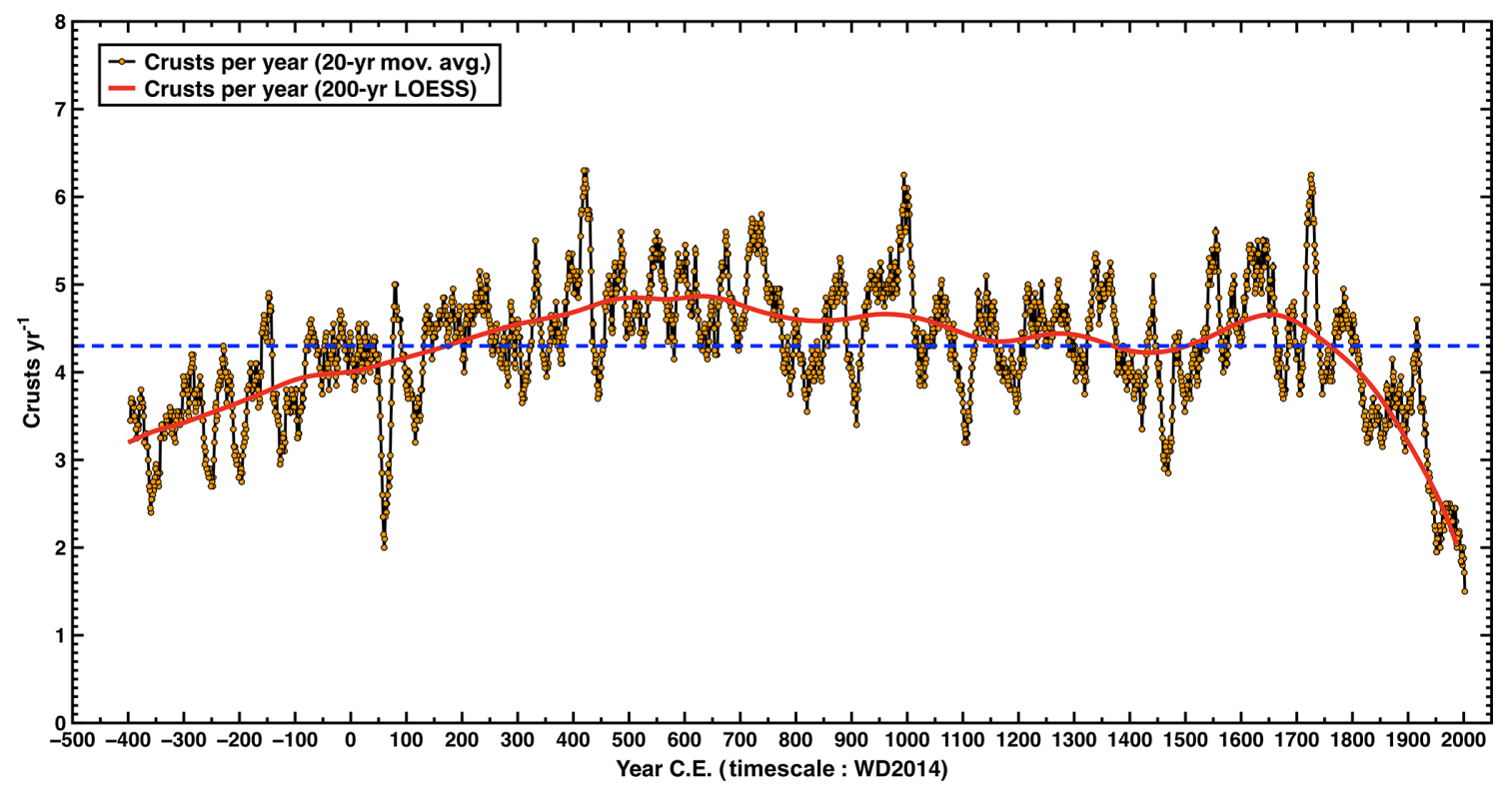

Figure 15. History of crust occurrence (crusts year ${ }^{-1}$ ) in the bubbly-ice zone of the WDC06A core that we studied in detail $(\sim 120-577 \mathrm{~m}$ depth); ages (CE) are from the WD2014 depth-age scale. A total of 10268 unique crusts were documented in the core, for an average rate of $4.3 \pm 2$ per year (dashed blue line). Data are shown as 20-year moving averages for ease of view, with an added 1st-order LOESS smoothing trend curve (200-year bin width). The sharp decline in crust prevalence after $\sim 1750 \mathrm{CE}$ may be due to observational biasing in the shallow firn and snow. 


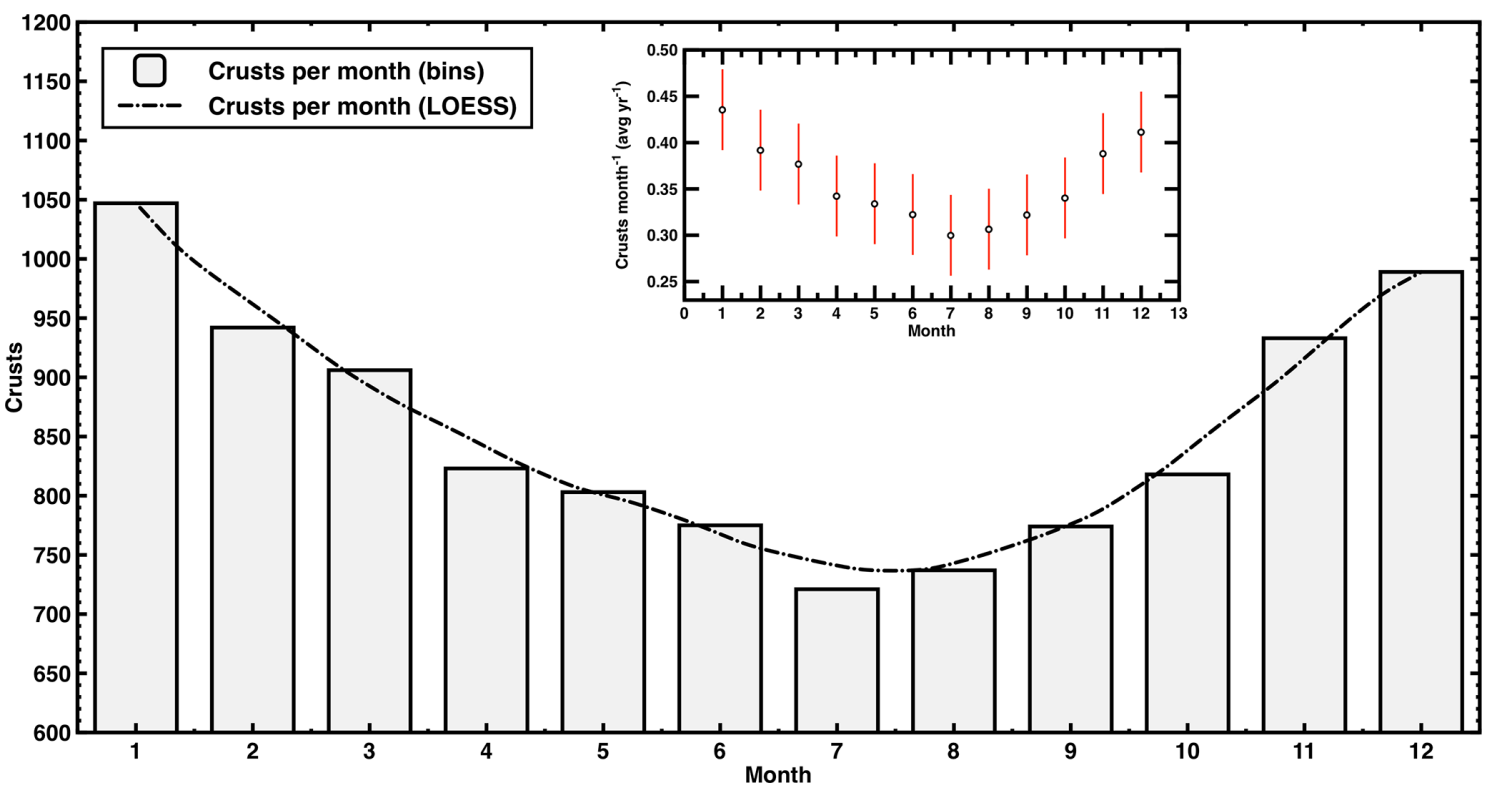

Figure 16. Crust distribution by month (1: January; 2: February; ...; 12: December) based on the assumption that each summer pick in the WD2014 depth-age scale is 1 January, and then interpolating linearly. Crusts occur year-round but more commonly in summer accumulation. The smoothed curve is a 1st-order LOESS trend curve (width =2). Data shown for 2400-year record. Inset shows average crusts per month $( \pm 1 \sigma)$.

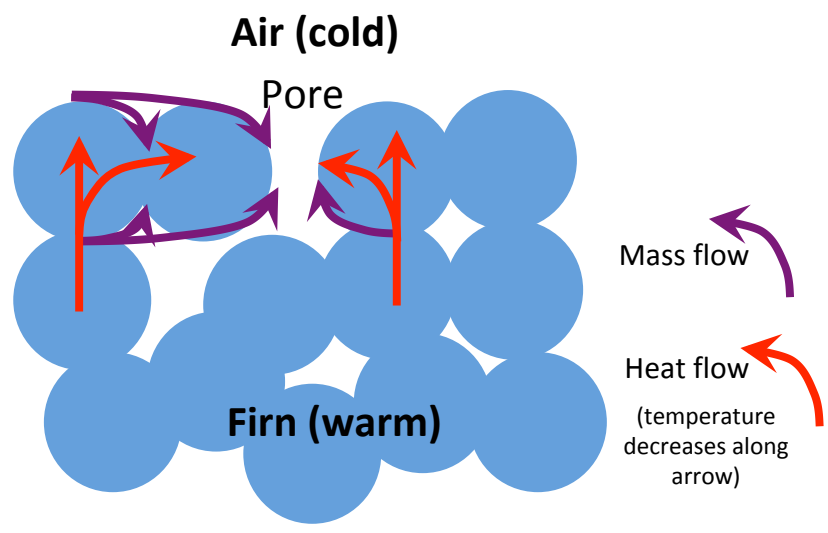

Figure 17. Schematic illustrating possible mass and heat transports during formation of a single-grain glazed crust, when the near-subsurface is warmer than the surface. Heat flow is primarily through the grain structure (blue), so pores (white) in the surface layer will be colder than interconnected grains, favoring mass transport from the grains to those pores, increasing density of the surface layer.

neath, favoring mass transport to the pore surfaces, as shown in Fig. 17 (e.g., Sommerfeld, 1983; Fukuzawa and Akitaya, 1993). Transport may occur by vapor, surface, or volume diffusion; following Alley and Fitzpatrick (1999), vapor diffusion and surface transport in premelted films are likely to dominate. Also, mass loss from relatively warm grain bonds just beneath a growing surface crust by diffusion to the colder crust will tend to lower the crust, increasing the likelihood that a pore in the crust will move downward to intersect a preexisting grain beneath, increasing the crust density.

Due to the inherent limitations with the available sensor equipment, and with the sparsity of usable data for our specific periods of interest, a complete and detailed analysis of radiative forcings was not completed here. However, to further test our hypothesis and to assess the accuracy of our measurements, we did execute a simple surface energy budget (SEB) calculation in order to solve for the ground heat flux term $Q_{\mathrm{G}}$ and ultimately determine if the AWS sensor data yield flux rates capable of the hypothesized vertical vapor transport in the near-surface snow. Because data from the AWS-mounted net radiometer and PRD strings were only available for the 2012-2013 field season, only that specific time window was used for this simple SEB calculation (see also Figs. 8 and 10).

The surface energy budget represents a balance of turbulent, radiative, and ground heat fluxes, which are all coupled through various processes (see, e.g., Hulth et al., 2010; Miller et al., 2017). Because there is no known or observed melting at the WAIS Divide site, and therefore no solid-liquid latent heat in the near-surface snow, a change in any of the SEB terms is thus balanced by changes in other terms. For simplicity, we represent this relationship here as

$$
\begin{aligned}
& Q_{\mathrm{N}}+Q_{\mathrm{S}}+Q_{\mathrm{L}}+Q_{\mathrm{G}}=0, \\
& Q_{\mathrm{N}}=S_{\mathrm{NET}}+L_{\mathrm{NET}}=S \downarrow+S \uparrow+L \downarrow+L \uparrow,
\end{aligned}
$$

where $Q_{\mathrm{N}}$ is the total net radiation ( $S_{\mathrm{NET}}$ and $L_{\mathrm{NET}}$ are the net short- and longwave radiation terms); $Q_{\mathrm{S}}$ and $Q_{\mathrm{L}}$ are 
the sensible and latent turbulent heat fluxes, respectively; and $Q_{\mathrm{G}}$ is the ground heat flux. The net radiation term $Q_{\mathrm{N}}$ was determined by combining the short- and longwave radiation data obtained directly from the radiometer (see Fig. 8). Due to limitations with the Kipp \& Zonen CNR2 sensor, only the radiative NET terms were available, not the individual incoming $(\downarrow)$ and outgoing $(\uparrow)$ terms.

Based upon the Monin-Obukhov similarity theory, the sensible and latent heat flux terms can be expressed as

$Q_{\mathrm{S}}=\rho c_{\mathrm{p}} u_{*} T_{*}$ and $Q_{\mathrm{L}}=\rho L_{\mathrm{S}} u_{*} q_{*}$,

where $\rho$ denotes air density, $c_{\mathrm{p}}$ is the specific heat of dry air at constant pressure $\left(1005 \mathrm{~J} \mathrm{~K}^{-1} \mathrm{~kg}^{-1}\right)$, and $L_{\mathrm{S}}=2.83 \times$ $10^{6} \mathrm{~J} \mathrm{~kg}^{-1}$ is the latent heat of sublimation. We use bulkmethod approximations for the turbulent scales of wind speed $\left(u_{*}\right)$, temperature $\left(T_{*}\right)$, and humidity $\left(q_{*}\right)$, and their related stability correction functions (Van As et al., 2005; Andreas, 2002; Fairall et al., 1996; Holtslag and DeBruin, 1988). We also employed an optimal velocity roughness length $(\sim 0.03 \mathrm{~mm})$ and calculated the related roughness terms using published equations (Miller et al., 2017; Van As et al., 2005; Andreas, 1987). As previously noted, relative humidity values reported here are expressed in terms of saturation vapor pressure over ice and corrected for lowtemperature offsets (see Anderson, 1994). Specific humidity is calculated from relative humidity using published equations (Van As et al., 2005).

Results of this SEB calculation are shown in Fig. S7, and values for ground heat flux were determined by solving Eq. (1) for $Q_{\mathrm{G}}$. Over the $\sim 24 \mathrm{~h}$ low-wind period shown highlighted in Fig. 8 that features a surface glaze (labeled "b"), the net ground heat flux $Q_{\mathrm{G}}$ does corroborate a condition favorable for upward (negative) energy flux, particularly during the morning hours of 24 December 2012.

We calculated thermal conductivity of the uppermost snow layers as $K=0.35 \pm 0.05 \mathrm{~W} \mathrm{~m}^{-1} \mathrm{~K}^{-1}$, from our measured snow pit density data (see Fig. 14), combined with published relations between density and $K$ (Miller et al., 2017; Jordan, 1991). Then, we used $K, Q_{\mathrm{G}}$, and the equation for conductive heat flux,

$Q_{\mathrm{G}}=-K \frac{\Delta T}{\Delta z}$,

to calculate vertical temperature difference $(\Delta T)$, over the top $20 \mathrm{~cm}(\Delta z)$ (Van As et al., 2005).

Our results yield an average vertical temperature difference of $\sim 3.6 \pm 0.7^{\circ} \mathrm{C}$ over the $\sim 24 \mathrm{~h}$ low-wind glaze period highlighted in Fig. 8, or a gradient of $\sim 18^{\circ} \mathrm{C} \mathrm{m}^{-1}$. This result is consistent with the PRD string data (see Figs. 10 and 11), which indicate a temperature difference between the near-surface air sensor (AWS) and the shallowest in-snow sensor (S1, $20 \mathrm{~cm}$ depth) of $\sim 3.0^{\circ} \mathrm{C}$ during the peak of the inversion and glazing episode on 24 December 2012; the near-surface air sensor was $\sim 1 \mathrm{~m}$ above the surface, and we infer that, as a result, it somewhat underestimated peak $\Delta T$.
Our energy-balance calculation, although simple, retains the key physics and follows earlier work. We thus trust the basic result, with agreement between model and measured temperatures, that the energy balance generates sufficient heat fluxes to drive the vapor mass transport needed for glazed-crust development (Pinzer et al., 2012). We are confident that a more comprehensive study extending this work would be instructive, with additional sampling and modeling addressing the overall radiative and SEB responses, boundary-layer stability responses, cloud forcings, and vapor mass flux rates.

Although summertime crusts dominate in the ice core, many wintertime crusts were identified, raising additional questions. We lack direct observations in winter and so can only speculate on mechanisms active then. However, the basic picture drawn above for summertime crusts may also apply in winter. The lower temperatures, and lack of intense solar heating, make crust formation less likely. However, stronger wintertime winds would allow greater wind packing of the upper surface, producing fewer and smaller pores to be filled to make a thin crust and thus making crust formation easier. Although accumulation is more or less evenly distributed through the year, long periods of limited variability observed in AWS data suggest that there may be extended intervals up to weeks in length during the winter when the surface is relatively stable, partially or completely offsetting the slower mass transport from colder temperatures. Furthermore, the AWS data show that mid-winter temperatures have risen as high as $-15^{\circ} \mathrm{C}$ during strong warming events accompanied by high winds $\left(>10 \mathrm{~ms}^{-1}\right)$, likely linked to transport of air masses from the coast. Such warm air masses paired with these high winds would produce relatively high vapor pressures, contribute to greater surface packing, and promote temperature inversions and upward near-surface vapor flux during the subsequent cooling.

The great abundance of crusts at WAIS Divide compared to other ice cores we have studied may be because conditions are "just right" at WAIS Divide. We have observed loss of a wind-packed crust at WAIS Divide, and also at GISP2 in central Greenland; the strong mass loss from the upper $\sim 1 \mathrm{~cm}$ of the snowpack is not conducive to long-term survival of any crust there (e.g., Alley et al., 1990). Low but nonzero summertime accumulation thus may lead to loss of crusts, whereas higher accumulation after formation buries them below that zone of mass loss and so allows their preservation. The large wintertime variability and high wintertime temperatures at WAIS Divide may be important in generating sufficiently high mass fluxes to produce wintertime crusts.

At least in summertime, crusts do seem to record a particular meteorological pattern of storms alternating with still conditions. The time series of frequency of occurrence of crusts thus would be affected by a change in the frequency of occurrence of these conditions. Turning this into a paleoclimatic indicator would require additional steps, however, as the frequency of preserved crusts could decrease because 
fewer were formed or because more were destroyed, with different causes. Information on changing frequency of meteorological events might be useful (e.g., Hammer, 1985; Alley, 1988). We believe that the clear association of crust formation with particular events and the clear trends in crust occurrence in the core motivate additional research on topics including crust formation in nonsummer seasons, but we do not know whether this ultimately could yield a valuable paleoclimatic indicator.

\section{Conclusions}

Summertime observations at the WAIS Divide site show that prominent visible strata form at or very near the surface during summer, by processes that typically are repeated a few times during each summer. A storm produces a wind-packed layer. The following high-pressure system brings light winds, warm days and cool nights, strong sunshine, and low relative humidity. High-density, single-grain-thick glazed crusts preferentially form at the surface during these high-pressure intervals, in as little as a single day, and then strengthen and evolve. Crusts are extensive, although typically broken by sub-meter or few-meter uncrusted regions spaced tens of meters to more than $100 \mathrm{~m}$ apart. Daytime solar heating drives upward mass transport to crusts from developing depth hoar beneath, strengthening the crusts. A simple surface energy budget calculation shows that sufficient vertical heat fluxes exist to explain both the observed near-surface temperature inversions and the vapor mass flux necessary for the associated glazed-crust formation. After formation, crusts are broken by polygonal cracks extending typically $20-30 \mathrm{~cm}$ deep, likely from contraction during nighttime cooling. Relative humidity then rises in the air above, contributing to growth of surface hoar during nighttime cooling. Subsequent storms typically bury the crust-hoar complexes, although crusts can be lost during evolving surface conditions if not buried below the top $1 \mathrm{~cm}$ to a few centimeters.

Study of the WAIS Divide deep core shows that crusts are preserved through the bubbly ice. Crusts are most common in layers deposited during summertime but also occur in winter accumulation. Study of AWS data suggests that the intrusion of warm coastal air during winter may generate strong temperature gradients, which may contribute to wintertime crust formation in wind-packed layers.

The frequency of occurrence of crusts in the core varies with time, suggesting the possibility that crusts could be used as a paleoclimatic indicator. However, additional work would be required, including addressing whether crust frequency varies because of changes in formation or changes in destruction of crusts previously formed. The crusts do not produce significant anomalies in other ice core paleoclimatic records, likely at least in part because they are discontinuous and broken by contraction cracks.
Data availability. Data policy: all data presented here are available via download from USAP-DC (https://doi.org/10.15784/601079, Fegyveresi and Alley, 2018) or from the WAIS Divide data portal (http://waisdivide.unh.edu).

\section{The Supplement related to this article is available online at https://doi.org/10.5194/tc-12-325-2018-supplement.}

Author contributions. AJO assisted with field observations and experiments. AM designed the near-surface PRD sensor strings and developed the associated logging code. MS documented all ice core crust observations during the WAIS Divide core processing at the National Ice Core Laboratory. JMF and RBA prepared the manuscript with contributions from all co-authors.

Competing interests. The authors declare that they have no conflict of interest.

Special issue statement. This article is part of the special issue "International Partnerships in Ice Core Sciences (IPICS) Second Open Science Conference (CP/TC inter-journal SI)". It is a result of the IPICS 2nd Open Science Conference, Hobart, Australia, 7-11 March 2016.

Acknowledgements. We acknowledge the following funding sources for support of this work: US National Science Foundation Division of Polar Programs grants 0539578, 1043528, 1142085, and 1619793. We also acknowledge Donald E. Voigt, Joan J. Fitzpatrick, Eric D. Cravens, and the staff of the US National Ice Core Laboratory in Denver, Colorado, as well as the WAIS Divide Science Coordination Office at the University of New Hampshire and the Ice Drilling Design and Operations group at the University of Wisconsin. We thank numerous colleagues involved with the WAIS Divide project, especially Kendrick Taylor, Mark Twickler, and Joseph Souney. We thank Bess Koffman, Gifford Wong, Dominic Winski, Aron Buffen, and Logan Mitchell for assistance with snow pit preparation. We thank Jonathan Thom and the University of Wisconsin-Madison Automatic Weather Station Program for assistance with weather station sensor installation. Lastly, we thank our reviewers, whose thoughtful suggestions and questions served to clarify and improve the manuscript. Any use of trade, firm, or product names is for descriptive purposes only and does not imply endorsement.

Edited by: Catherine Ritz

Reviewed by: Martin Schneebeli and one anonymous referee 


\section{References}

Alley, R. B.: Concerning the deposition and diagenesis of strata in polar firn, J. Glaciol., 34, 283-290, https://doi.org/10.3189/S0022143000007024, 1988.

Alley, R. B. and Fitzpatrick, J. J.: Conditions for bubble elongation in cold ice-sheet ice, J. Glaciol., 45, 147-153, https://doi.org/10.3189/S0022143000003129, 1999.

Alley, R. B., Saltzman, E. S., Cuffey, K. M., and Fitzpatrick, J. J.: Summertime formation of depth hoar in central Greenland, Geophys. Res. Lett., 17, 2393-2396, https://doi.org/10.1029/GL017i013p02393, 1990.

Alley, R. B., Shuman, C. A., Meese, D. A., Gow, A. J., Taylor, K. C., Cuffey, K. M., Fitzpatrick, J. J., Grootes, P. M., Zielinski, G. A., Ram, M., and Spinelli, G.: Visual-stratigraphic dating of the GISP2 ice core: basis, reproducibility, and application, J. Geophys. Res.-Oceans, 102, 26367-26381, https://doi.org/10.1029/96JC03837, 1997.

Anderson, P. S.: A method for rescaling humidity sensors at temperatures well below freezing, J. Atmos. Ocean. Technol., 11, 1388-1391, https://doi.org/10.1175/15200426(1994)011<1388:AMFRHS>2.0.CO;2, 1994.

Anderson, D. L. and Benson, C. S.: The densification and diagenesis of snow, in Ice and Snow: Properties, Processes and Applications, edited by: Kingery, W. D., MIT Press, Cambridge, MA, 391-411, 1963.

Andreas, E. L.: A theory for the scalar roughness and the scalar transfer coefficients over snow and sea ice, Bound.-Lay. Meteorol., 38, 159-184, https://doi.org/10.1007/BF00121562, 1987.

Andreas, E. L.: Parameterizing scalar transfer over snow and ice: a review, J. Hydrometeorol., 3, 417-432, https://doi.org/10.1175/15257541(2002)003<0417:PSTOSA>2.0.CO;2, 2002.

Banta, J. R., McConnell, J. R., Frey, M. M., Bales, R. C., and Taylor, K.: Spatial and temporal variability in snow accumulation at the West Antarctic Ice Sheet Divide over recent centuries, J. Geophys. Res.-Atmos., 113, D23102, https://doi.org/10.1029/2008JD010235, 2008.

Battle, M. O., Severinghaus, J. P., Sofen, E. D., Plotkin, D., Orsi, A. J., Aydin, M., Montzka, S. A., Sowers, T., and Tans, P. P.: Controls on the movement and composition of firn air at the West Antarctic Ice Sheet Divide, Atmos. Chem. Phys., 11, 1100711021, https://doi.org/10.5194/acp-11-11007-2011, 2011.

Benson, C. S.: Stratigraphic studies on Greenland ice sheet and a quantitative classification of glaciers, B. Am. Meteorol. Soc., 43, p. 141, Boston, MA, 1962.

Brandt, R. E. and Warren, S. G.: Solar-heating rates and temperature profiles in Antarctic snow and ice, J. Glaciol., 39, 99-110, https://doi.org/10.3189/S0022143000015756, 1993.

Buizert, C., Cuffey, K. M., Severinghaus, J. P., Baggenstos, D., Fudge, T. J., Steig, E. J., Markle, B. R., Winstrup, M., Rhodes, R. H., Brook, E. J., Sowers, T. A., Clow, G. D., Cheng, H., Edwards, R. L., Sigl, M., McConnell, J. R., and Taylor, K. C.: The WAIS Divide deep ice core WD2014 chronology - Part 1: Methane synchronization (68-31 ka BP) and the gas age-ice age difference, Clim. Past, 11, 153-173, https://doi.org/10.5194/cp11-153-2015, 2015.

Burgener, L., Rupper, S., Koenig, L., Forster, R., Christensen, W. F., Williams, J., Koutnik, M., Miege, C., Steig, E. J., Tingey, D., Keeler, D., and Riley, L.: An observed negative trend in Antarc- tic accumulation rates from 1975 to 2010: evidence from new observed and simulated records, J. Geophys. Res.-Atmos., 118, 4205-4216, https://doi.org/10.1002/jgrd.50362, 2013.

Champollion, N., Picard, G., Arnaud, L., Lefebvre, E., and Fily, M.: Hoar crystal development and disappearance at Dome C, Antarctica: observation by near-infrared photography and passive microwave satellite, The Cryosphere, 7, 1247-1262, https://doi.org/10.5194/tc-7-1247-2013, 2013.

Colbeck, S. C.: An overview of seasonal snow metamorphism, Rev. Geophys., 20, 45-61, https://doi.org/10.1029/RG020i001p00045, 1982.

Colbeck, S. C.: Theory of metamorphism of dry snow, J. Geophys. Res.-Oceans, 88, 5475-5482, https://doi.org/10.1029/JC088iC09p05475, 1983.

Conger, S. M. and McClung, D. M.: Comparison of density cutters for snow profile observations, J. Glaciol., 55, 163-169, https://doi.org/10.3189/002214309788609038, 2009.

Criscitiello, A. S., Das, S. B., Karnauskas, K. B., Evans, M. J., Frey, K. E., Joughin, I., Steig, E. J., McConnell, J. R., and Medley, B.: Tropical Pacific influence on the source and transport of marine aerosols to West Antarctica, J. Climate, 27, 1343-1363, https://doi.org/10.1175/JCLI-D-13-00148.1, 2014.

Das, S. B. and Alley, R. B.: Characterization and formation of melt layers in polar snow: observations and experiments from West Antarctica, J. Glaciol., 51, 307-312, https://doi.org/10.3189/172756505781829395, 2005.

Dash, J. G., Rempel, A. W., and Wettlaufer, J. S.: The physics of premelted ice and its geophysical consequences, Rev. Mod. Phys., 78, 695-741, https://doi.org/10.1103/RevModPhys.78.695, 2006.

Fairall, C. W., Bradley, E. F., Rogers, D. P., Edson, J. B., and Young, G. S.: Bulk parameterization of air-sea fluxes for tropical ocean-global atmosphere coupled-ocean atmosphere response experiment, J. Geophys. Res.-Oceans, 101, 3747-3764, https://doi.org/10.1029/95JC03205, 1996.

Fegyveresi, J. M.: Physical Properties of the West Antarctic Ice Sheet (WAIS) Divide Deep Core: Development, Evolution, and Interpretation, PhD Thesis, The Pennsylvania State University, State College, PA, 2015.

Fegyveresi, J. M. and Alley, R. B.: WAIS Divide Surface and Snowpit Data, 2009-2013, U.S. Antarctic Program (USAP) Data Center, Dataset, available at: https://doi.org/10.15784/601079, last access: 16 January 2018.

Fegyveresi, J. M., Alley, R. B., Fitzpatrick, J. J., Cuffey, K. M., McConnell, J. R., Voigt, D. E., Spencer, M. K., and Stevens, N. T.: Five millennia of surface temperatures and ice core bubble characteristics from the WAIS Divide deep core, West Antarctica, Paleoceanography, 31, 416-433, https://doi.org/10.1002/2015PA002851, 2016.

Fitzpatrick, J. J., Voigt, D. E., Fegyveresi, J. M., Stevens, N. T., Spencer, M. K., Cole-Dai, J., Alley, R. B., Jardine, G. E., Cravens, E. D., Wilen, L. A., and Fudge, T. J.: Physical properties of the WAIS Divide ice core, J. Glaciol., 60, 1181-1198, https://doi.org/10.3189/2014JoG14J100, 2014.

Fukuzawa, T. and Akitaya, E.: Depth-hoar crystal-growth in the surface-layer under high-temperature gradient, Ann. Glaciol., 18, 39-45, https://doi.org/10.1017/S026030550001123X, 1993.

Gallet, J.-C., Domine, F., Savarino, J., Dumont, M., and Brun, E.: The growth of sublimation crystals and surface hoar 
on the Antarctic plateau, The Cryosphere, 8, 1205-1215, https://doi.org/10.5194/tc-8-1205-2014, 2014.

Gow, A.: On the accumulation and seasonal stratification of snow at the South Pole, J. Glaciol., 5, 467-477, https://doi.org/10.3189/S002214300001844X, 1965.

Gow, A.: On the rates of growth of grains and crystals in south polar firn, J. Glaciol., 8, 241-252, https://doi.org/10.3189/S0022143000031233, 1969.

Hammer, C. U.: The influence on atmospheric composition of volcanic eruptions as derived from ice-core analysis, Ann. Glaciol., 7, 125-129, https://doi.org/10.1017/S0260305500006029, 1985.

Holtslag, A. A. M. and De Bruin, H. A. R.: Applied modeling of the nighttime surface energy balance over land, J. Appl. Meteorol., 27, 689-704, https://doi.org/10.1175/15200450(1988)027<0689:AMOTNS>2.0.CO;2, 1988.

Hulth, J., Rolstad, C., Trondsen, K., and Rødby, R. W.: Surface mass and energy balance of Sørbreen, Jan Mayen, 2008, Ann. Glaciol., 51, 110-119, https://doi.org/10.3189/172756410791392754, 2010.

Jordan, R.: A one-dimensional temperature model for a snow cover: Technical documentation for SNTHERM.89, Special Report 9116, Cold Regions Research and Engineering Laboratory (US) and Engineer Research and Development Center (US), Hanover, NH, 1991.

Koerner, R. M.: A stratigraphic method of determining the snow accumulation at Plateau Station, Antarctica, and application to South Pole-Queen Maud Land traverse 2, 1965-1966, in: Antarctic Snow and Ice Studies II, edited by: Crary, A. P., American Geophysical Union, Washington, DC, 225-238, 1971.

Koffman, B. G., Kreutz, K. J., Breton, D. J., Kane, E. J., Winski, D. A., Birkel, S. D., Kurbatov, A. V., and Handley, M. J.: Centennial-scale variability of the Southern Hemisphere westerly wind belt in the eastern Pacific over the past two millennia, Clim. Past, 10, 1125-1144, https://doi.org/10.5194/cp-10-11252014, 2014.

Lazzara, M. A., Weidner, G. A., Keller, L. M., Thom, J. E., and Cassano, J. J.: Antarctic automatic weather station program 30 years of polar observations, B. Am. Meteorol. Soc., 93, 15191537, https://doi.org/10.1175/BAMS-D-11-00015.1, 2012.

Miller, N. B., Shupe, M. D., Cox, C. J., Noone, D., Persson, P. O. G., and Steffen, K.: Surface energy budget responses to radiative forcing at Summit, Greenland, The Cryosphere, 11, 497516, https://doi.org/10.5194/tc-11-497-2017, 2017.

Mitchell, L. E., Buizert, C., Brook, E. J., Breton, D. J., Fegyveresi, J., Baggenstos, D., Orsi, A., Severinghaus, J., Alley, R. B., Albert, M., and Rhodes, R. H.: Observing and modeling the influence of layering on bubble trapping in polar firn, J. Geophys. Res.-Atmos., 120, 2558-2574, https://doi.org/10.1002/2014JD022766, 2015.
Muto, A., Scambos, T. A., Steffen, K., Slater, A. G., and Clow, G. D.: Recent surface temperature trends in the interior of East Antarctica from borehole firn temperature measurements and geophysical inverse methods, Geophys. Res. Lett., 38, L15502, https://doi.org/10.1029/2011GL048086, 2011.

Orsi, A. J., Kawamura, K., Fegyveresi, J. M., Headly, M. A., Alley, R. B., and Severinghaus, J. P.: Differentiating bubble-free layers from melt layers in ice cores using noble gases, J. Glaciol., 61, 585-594, https://doi.org/10.3189/2015JoG14J237, 2015.

Pinzer, B. R., Schneebeli, M., and Kaempfer, T. U.: Vapor flux and recrystallization during dry snow metamorphism under a steady temperature gradient as observed by time-lapse micro-tomography, The Cryosphere, 6, 1141-1155, https://doi.org/10.5194/tc-6-1141-2012, 2012.

Sigl, M., Fudge, T. J., Winstrup, M., Cole-Dai, J., Ferris, D., McConnell, J. R., Taylor, K. C., Welten, K. C., Woodruff, T. E., Adolphi, F., Bisiaux, M., Brook, E. J., Buizert, C., Caffee, M. W., Dunbar, N. W., Edwards, R., Geng, L., Iverson, N., Koffman, B., Layman, L., Maselli, O. J., McGwire, K., Muscheler, R., Nishiizumi, K., Pasteris, D. R., Rhodes, R. H., and Sowers, T. A.: The WAIS Divide deep ice core WD2014 chronology Part 2: Annual-layer counting (0-31 ka BP), Clim. Past, 12, 769786, https://doi.org/10.5194/cp-12-769-2016, 2016.

Sommerfeld, R. A.: A branch grain theory of temperature gradient metamorphism in snow, J. Geophys. Res.-Oceans, 88, 1484 1494, https://doi.org/10.1029/JC088iC02p01484, 1983.

Sorge, E.: Glaziologische Untersuchungen in Eismitte, in: Glaziologie, edited by: Brockamp, B., and others, Leipzig, FA Brockhaus, 935, 62-270, 1935.

Van As, D., Van Den Broeke, M., and Van De Wal, R.: Daily cycle of the surface layer and energy balance on the high Antarctic Plateau, Antarct. Sci., 17, 121-133, https://doi.org/10.1017/S095410200500252X, 2005.

WAIS Divide Project Members: Onset of deglacial warming in West Antarctica driven by local orbital forcing, Nature, 500, 440-444, https://doi.org/10.1038/nature12376, 2013.

Weller, G.: The heat and mass balance of snow dunes on the central Antarctic Plateau, J. Glaciol., 8, 277-284, https://doi.org/10.3189/S0022143000031257, 1969. 